Research article

urn:1sid:zoobank.org:pub:51C2BE54-B99B-4464-8FC1-28A5CC6B9586

\title{
A new species of freshwater Chaetonotidae (Gastrotricha, Chaetonotida) from Obodska Cave (Montenegro) based on morphological and molecular characters
}

\author{
Małgorzata KOLICKA ${ }^{1, *}$, Piotr GADAWSKI ${ }^{2} \&$ Miroslawa DABERT $^{3}$ \\ ${ }^{1}$ Department of Animal Taxonomy and Ecology, Institute of Environmental Biology, \\ Adam Mickiewicz University Poznan, Umultowska 89, 61-614 Poznan, Poland. \\ ${ }^{2}$ Department of Invertebrate Zoology and Hydrobiology, University of Łódź, \\ Banacha 12/16, 90-237 Łódź, Poland. \\ ${ }^{3}$ Molecular Biology Techniques Laboratory, Faculty of Biology, Adam Mickiewicz University Poznan, \\ Umultowska 89, 61-614 Poznan, Poland. \\ *Corresponding author: kolicka@amu.edu.pl \\ ${ }^{2}$ E-mail: gadawski@biol.uni.lodz.pl \\ ${ }^{3}$ E-mail: mirkad@amu.edu.pl \\ ${ }^{1}$ urn:1sid:zoobank.org:author:550BCAA1-FB2B-47CC-A657-0340113C2D83 \\ ${ }^{2}$ urn:lsid:zoobank.org:author:BCA3F37A-28BD-484C-A3B3-C2169D695A82 \\ ${ }^{3}$ urn:Isid:zoobank.org:author:8F04FE81-3BC7-44C5-AFAB-6236607130F9
}

\begin{abstract}
Gastrotricha is a cosmopolitan phylum of aquatic and semi-aquatic invertebrates that comprises about 820 described species. Current knowledge regarding freshwater gastrotrichs inhabiting caves is extremely poor and there are no extant data regarding Gastrotricha from Montenegro. We describe a new species from Obodska Cave, which is also the first record of a gastrotrich from this region. Due to its unusual habitat and morphological characteristics, this species may be important when considering the evolution and dispersion routes of Chaetonotidae Gosse, 1864 (sensu Leasi \& Todaro 2008). We provide morphometric, molecular and phylogenetic data for the new species, together with photomicrographs and drawings.
\end{abstract}

Keywords. Balkan Peninsula, cave fauna, Chaetonotus (Chaetonotus) antrumus sp. nov., DNA barcode, Gastrotricha.

Kolicka M., Gadawski P. \& Dabert M. 2017. A new species of freshwater Chaetonotidae (Gastrotricha, Chaetonotida) from Obodska Cave (Montenegro) based on morphological and molecular characters. European Journal of Taxonomy 354: 1-30. https://doi.org/10.5852/ejt.2017.354

\section{Introduction}

The eumetazoan meiofauna is considered a significant component of both rocky and soft bottoms of various natural aquatic ecosystems (Giere 2009). The meiofauna is an important source of food for macrofauna, small fish, juveniles of large fish and other epibenthic predators (Danovaro et al. 2007). 
While trophic connections within meiofaunal assemblages are not particularly well studied, there is evidence to suggest that changes in community structure may affect higher and lower trophic levels (McCall \& Fleeger 1995; Danovaro et al. 2007; Giere 2009). Moreover, meiofauna feeds on detritus, prokaryotes and microscopic eukaryotes and, therefore, plays essential roles in modulation of nutrient cycling processes, secondary production, sediment transport and detritus remineralization (Nozais et al. 2005; Danovaro et al. 2008). Due to their life cycle characteristics (small size, high turnover and lack of pelagic larval dispersal), these organisms are highly sensitive to environmental disturbance and respond rapidly to changes in food availability (Danovaro 1996; Fraschetti et al. 2006).

Within the meiofauna, gastrotrichs are microscopic free-living acoelomate eumetazoans with a total body length from 50 to $3500 \mu \mathrm{m}$ (e.g., Kisielewski 1997; Balsamo et al. 2014; Kieneke \& Schmidt-Rhaesa 2015). They inhabit all types of aquatic (fresh, brackish and marine waters) and semi-terrestrial ecosystems (e.g., peat bogs, sedge swamps and alder forests) throughout the world (Kisielewski 1981, 1997; Balsamo et al. 2008, 2014; Kieneke \& Schmidt-Rhaesa 2015). Currently, there are about 820 known species of Gastrotricha belonging to two orders: Chaetonotida Remane, 1925 [Rao \& Clausen, 1970] and Macrodasyida Remane, 1925 [Rao \& Clausen, 1970] (Balsamo et al. 2009; Hummon \& Todaro 2010; Kieneke \& Schmidt-Rhaesa 2015; Todaro 2016). Gastrotrichs are known from across the globe, but not all regions have been studied equally. Europe is the most thoroughly studied continent with respect to the gastrotrich fauna, with ca 225 freshwater and ca 150 marine species described (Balsamo et al. 2015; Todaro 2016). However, some countries have been studied relatively well, while others are still blank areas on a map of gastrotrich research; for example, Poland is a country with one of the longest histories of detailed studies on gastrotrichs with 100 freshwater (Kisielewski 1997; Kolicka et al. 2013; Kolicka 2016) and 31 marine species currently known (Kisielewski 1997; Kolicka et al. 2014, 2015). At the same time there are no data available on the freshwater gastrotrich fauna of countries like Portugal, The Netherlands, Albania, Serbia and Montenegro (Balsamo et al. 2008, 2014, 2015). The number of species recorded on other continents, including the tropical regions, is even lower, especially when compared with the potential species richness of those areas: there are ca 75 freshwater species of Gastrotricha known from North America, ca 95 from South America, ca 65 from Asia and 10 species from Africa and Australia (Balsamo et al. 2008, 2014). Moreover, there are no data on the occurrence of Antarctic freshwater Gastrotricha (Balsamo et al. 2008, 2014; Todaro 2016).

Until now, there has been research on neither the freshwater nor the marine gastrotrich fauna in Montenegro or even in all of the Balkan Peninsula region (except Romania), despite the fact that both the high average annual temperature and the diversity of aquatic habitats in this area are favourable to the presence of diverse and abundant gastrotrich communities. During the past five decades, the biota inhabiting dark caves has attracted the attention of many biologists. Cave waters host a great variety of species associated only with this type of habitat, and are often characterized by very restricted geographic distributions (Jones et al. 2003). However, studies of the meiofauna of these peculiar biotopes are still very scarce. So far, Gastrotricha associated with inland caves has only been reported once (Vandel 1964), but not identified to the species level. The only comprehensive study on the gastrotrich fauna in a cave habitat was carried out in a sea cave, 'Grotta Piccola del Ciolo', by Todaro et al. (2006), who revealed that cave ecosystems can be hotspots of biodiversity and endemism for marine Gastrotricha. It is possible that further research of inland caves might result in similar conclusions regarding freshwater gastrotrichs. The new species described in this study will turn out to be crucial in considering representatives of Chaetonotida as typical cavernicolous organisms (Vandel 1964). Such recognition is highly important for further studies of the adaptation, evolution and dispersal routes of freshwater Gastrotricha. 


\section{Material and methods}

\section{Study area}

This study was performed in the Obodska Cave $\left(42^{\circ} 21.118^{\prime} \mathrm{N}, 19^{\circ} 0.304^{\prime} \mathrm{E}\right)$, which is located west of the Rijeka Crnojevica, in the cadastral municipality of Ljubotinj II, Montenegro (Fig. 1). The area is not cultivated and most of the natural vegetation is still intact. The landscape is mostly covered with deciduous forest. The climate is classified as humid subtropical (no dry season, hot summer), with a temperate warm and wet forest biozone (Bonada et al. 2008). The area is high in leptosol (lp), a weakly developed shallow soil. Cetinje field and its surroundings are inclined to the southeast toward Skadar Lake, which causes gravity flows of groundwater in that direction (Bonada et al. 2008). There are numerous caves and cavities in this region, indicating the degree and depth of karstification. Cavities are vertical or horizontal with an opening on the surface. In most cases they are located in areas of vertical cracks or fracture systems, where extended karst processes occur on the tectonic lines and on the contact zone between limestone and dolomite (Martinović 1964; Lješević 1968; Doderović et al. 2013).

Obodska Cave is a deep cave with the spring-fed Crnojevica River flowing through it (Figs 2-3). The major part of the cave is formed beneath Pecki Hill. The Crnojevica River flows into the cave through

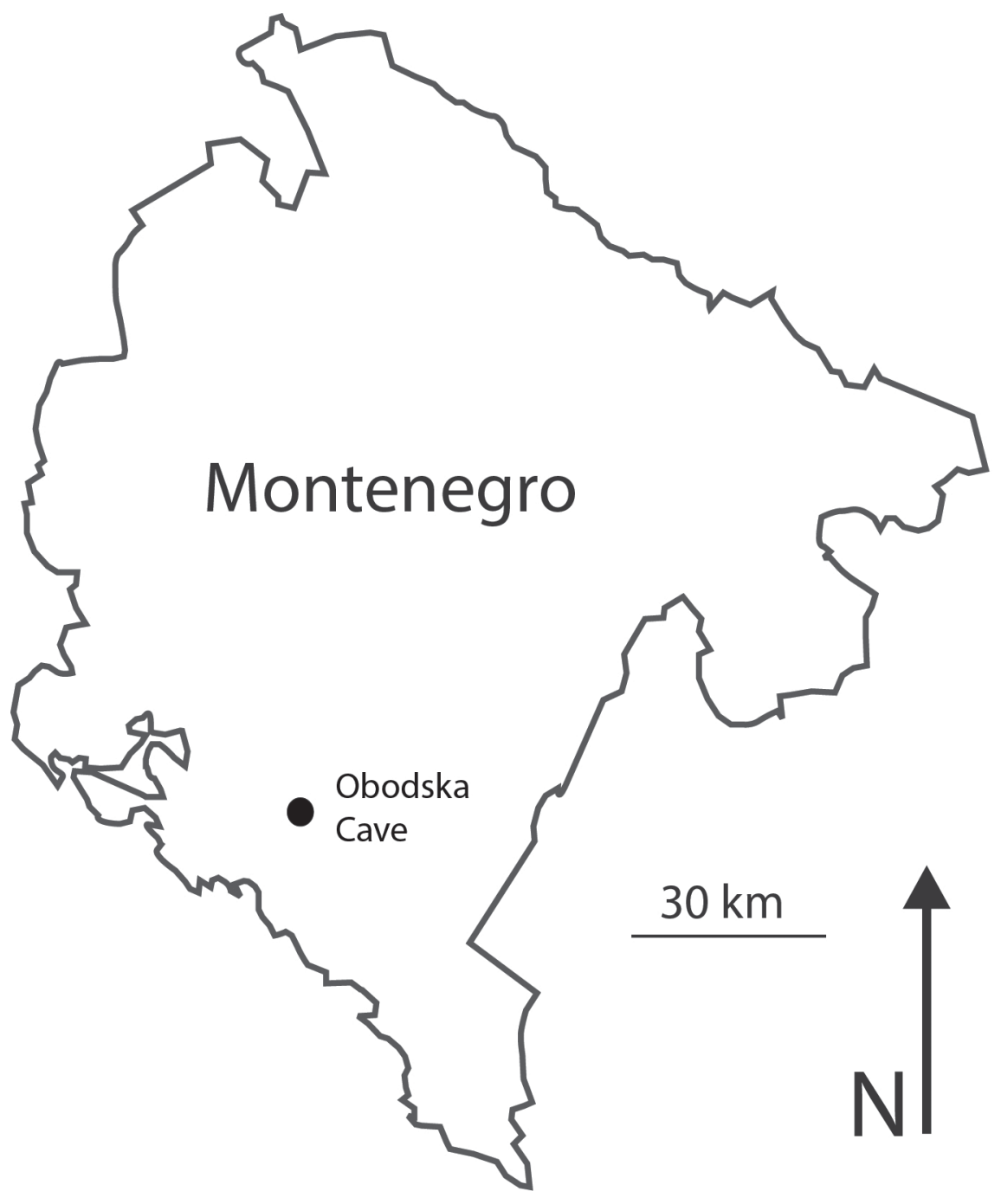

Fig. 1. Map of Montenegro with the location of Obodska Cave. 
a trench that plunges beneath the surface at the foot of Pecki Hill. Obodska Cave was created from stratified limestone, where edges of layers create horns visible on the vault. The sides and bottom of the upper channels are polished, in places, with narrow shelves on the horns of the layers. The cave is situated on three to five morphological levels (Palmer 1991). The total length of the cave is more than 350 meters and comprises three compartments connected by two siphons. The cave was formed through erosion by an underground river flowing along the initial chasm. The river flowed fast through stones and gravel in the whole cave and left holes in the solid rock (Martel 1893). Water in the cave leads to a humid microclimate (Obodska Cave has a precipitation/potential evapotranspiration index higher than 0.65) (Martel 1893; Lješević 1968; Mihavc 1983). Obod spring is characterized by a very variable flow that ranges from a minimum of $0.24 \mathrm{~m}^{3} / \mathrm{s}$ to a maximum of $46 \mathrm{~m}^{3} / \mathrm{s}$. Typically, the minimum water level occurs in November or December, and the maximum occurs in March or April, or rarely in February. The first post-summer minimum peak in flow is caused by minimal autumn rainfall and high temperatures, while the maximum peak in flow is due to rain with snow and low temperatures. The low precipitation in Cetinje field and its adjacent surroundings results from a lack of water streams on land surface (Martinović 1964; Lješević 1969; Radulović \& Radulović 2004).

The entrance to the cave is situated at $375 \mathrm{~m}$ above sea level, and the lowest point of the cave reaches an elevation of $244 \mathrm{~m}$ (192 m below the cave entrance). The main channel of the cave is divided by two siphons and creates the upper and lower channel. The lower channel is only partially passable (Mihavc 1983).

Obodska Cave was created in several morphological and hydrological stages. The main upper channel with a constant water flow was created during the first stage, when narrow pits were created at the bottom of the channel. The extension of the pits gradually allowed an increase of the amount of water that plunged through them and formed the second channel. This bifurcation of the channel has migrated during the second stage of development from a point close to the cave entrance to a point 45 meters from the entrance to the cave, where it is currently located. The third stage was characterized by the further scouring of the cave by the water flow, so that the upper part of the channel became dry. It is impossible to observe the bifurcation, because the lower water plunges through sinkholes in the bottom

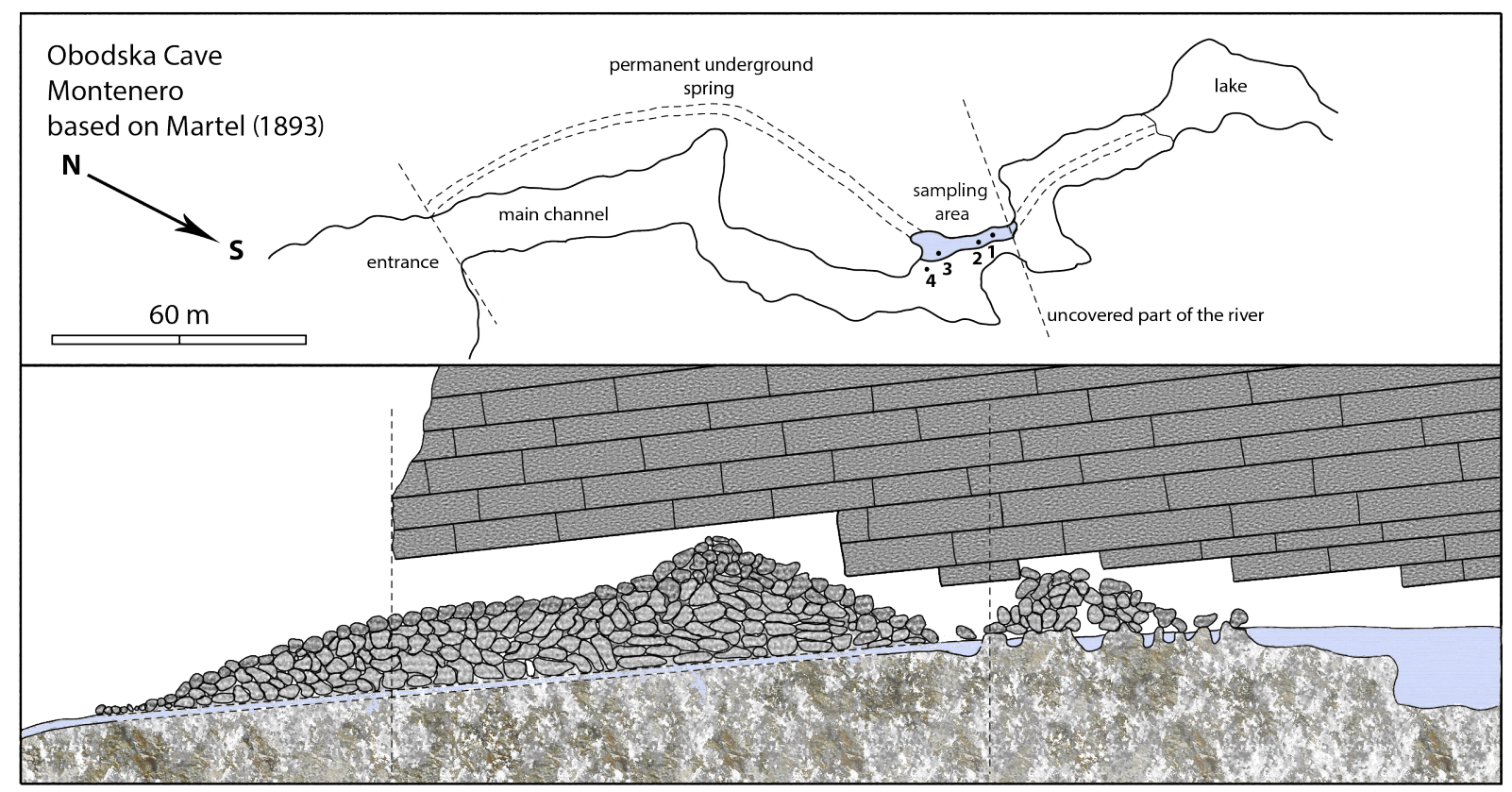

Fig. 2. Scheme of Obodska Cave. 1, 2, 3, 4 = sampling localities. 
and flows through cave channels underground. All this shows that there is another, lower cave channel, which today contains warm water. The genesis of this cave and its water flow reflect the typical lowering of the underground water flow in karst. Finally, it should be noted that the regime of the Crnojevic springs, which emerge from the cave, is very uneven. The flow of water fluctuates from 0.03 to $2 \mathrm{~m}^{3}$ per year (Dinić 1965). A few endemic species of invertebrates are known from this cave, e.g., Amphipoda: Metohija carinata Absolon, 1927; Gastropoda: Plagigeyeria montenigrina Bole, 1961 and Coleoptera: Adriaphaenops stirni Pretner, 1959. They occur only there or in a few other caves on the Adriatic coast (Pretner 1972; Pešić 2010; Hou \& Sket 2015).

\section{Sampling and documentation}

One sample of approximately $50-70 \mathrm{~cm}^{3}$ from the top layer of the bottom sediment, together with approximately $100-120 \mathrm{~cm}^{3}$ of ambient water, was collected from each of 4 sites within one locality on 29 July 2015. Each sample was placed in a $200 \mathrm{~cm}^{3}$ plastic container. The sampling area was situated at the end of the middle compartment approximately 150 meters from the entrance to the cave. Samples were collected in an area not covered by stones and gravel close to the second siphon, connecting the second and third compartments. Four samples were collected from different parts of the river channel: (1) in the main channel at a depth of $0.4 \mathrm{~m}$, (2) from the main channel at a depth of $0.25 \mathrm{~m}$, (3) from shallows at a depth of $0.1 \mathrm{~m}$, and (4) from pockets among stones and gravel. The last sample (4) was collected from a place where water filled the space between stones and boulders which had fallen from the roof of the cave. The sampling locations were separated by no less than $2 \mathrm{~m}$ (Fig. 2).

Water parameters, such as temperature, $\mathrm{pH}$, electrolytic conductivity and dissolved oxygen content, were measured in the field with an Elmetron CX-401 multiparametric sampling probe; BOD5 by Winkler's method, and $\mathrm{NH}_{4}, \mathrm{NO}_{3}, \mathrm{PO}_{3}$ with a Slandi LF205 photometer. The collected samples were subsequently placed in an insulated box and transported to the laboratory, where the samples were oxygenated and held at $12^{\circ} \mathrm{C}$ in order to create conditions similar to those at the sampling site. Within 10 days after collection, a total of $2 \mathrm{~cm}^{3}$ of sediment from each sample was searched for gastrotrichs. Specimens were extracted with a micropipette under an Olympus SZ51 stereo microscope. All specimens were observed, photographed and documented alive with an Olympus BX53 microscope equipped with phase contrast and an Array Artcam 500 digital camera or a Leica DM 5500 B microscope equipped with
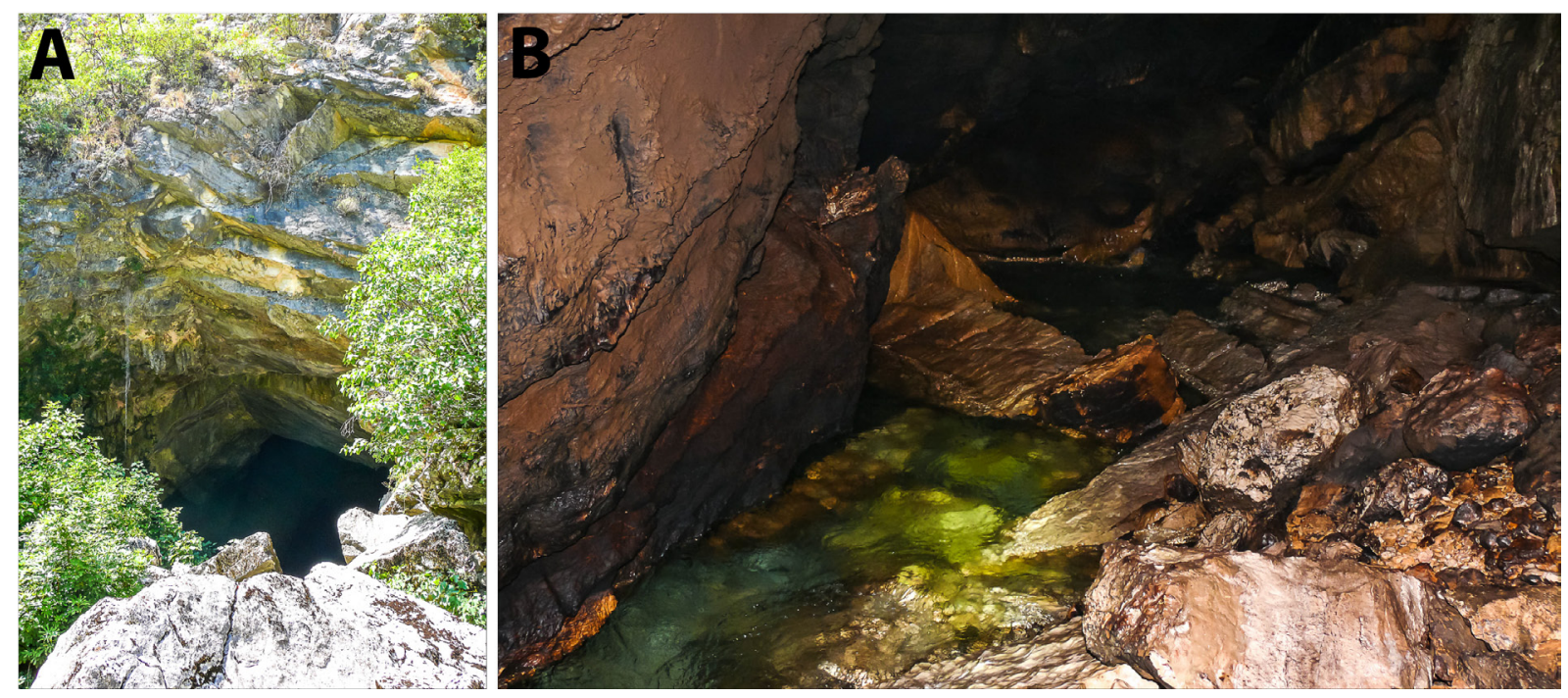

Fig. 3. Photographs of Obodska Cave. A. Entrance to the Cave. B. Sampling area inside the Cave. (Photographs by Przemysław Śmietana.) 
differential interference contrast (DIC) and a Leica DFC 450 digital camera. Morphometric characters were measured in cellSens Entry 1.11 software (Olympus). All measurements are given in micrometers $(\mu \mathrm{m})$ and all formulas used are given as a percentage $(\%)$.

\section{Granulometric analyses}

To determine the grain-size properties, the granulometric protocol described by Buchanan (1984) was applied. The grain-size statistics were calculated through Gradistat software using a logarithmic method of moments (Blott \& Pye 2001) and sediments were classified according to the Folk and Ward system (Folk \& Ward 1957). The organic matter content of the same sediment samples was determined using the combustion method. The main results of the granulometric analyses are provided in Table 1.

\section{Morphological analyses}

A morphological feature was measured only if its orientation was conducive to accurate measurement. Ranges of measurements are presented. Each of the specimens was documented by means of a set of photomicrographs. The species description follows the convention of Hummon et al. (1992), in which the longitudinal distance of a morphological character from the anterior end is expressed as percentage units (U) of the animal's total length (i.e., the distance of the character from the anterior end, divided by the total body length, and multiplied by 100). The identification of gastrotrichs, their morphological study and terms follows Kisielewski $(1981,1991,1997)$ and Kolicka et al. (2016). The terms describing the shape of furcal branches and furcal indentation follows Roszczak (1969). In this paper, the following formula describing the distribution of scales was used:

$$
\text { Ratio of scales distribution }=\frac{\text { total number of longitudinal alternating rows of scales }}{\text { number of scales in central longitudinal row }} \times 100 \%
$$

as well as the pharynx formulae according to Kisielewski (1991):

$$
\begin{array}{ll}
a=\frac{\text { width of anterior thickening }}{\text { pharynx length }} \times 100 \% & n=\frac{\text { width of pharynx narrowing }}{\text { pharynx length }} \times 100 \% \\
m=\frac{\text { width of middle pharynx }}{\text { pharynx length }} \times 100 \% & p=\frac{\text { width of anterior thickening }}{\text { pharynx length }} \times 100 \%
\end{array}
$$

Abbreviations used: $\mathrm{D}=$ dorsal; $\mathrm{DL}=$ dorsolateral; $\mathrm{L}=$ lateral; $\mathrm{LV}=$ ventrolateral; $\mathrm{V}=$ ventral.

The new species proposed in this paper is described by the first author only. This solution is consistent with chapter 11, article 50 of the International Code of Zoological Nomenclature (The International Commission on Zoological Nomenclature 1999).

\section{Molecular analyses}

Total genomic DNA was extracted from three single specimens of the new species using the DNeasy Blood and Tissue Kit (Qiagen GmbH, Hilden, Germany) as described by Dabert et al. (2008). A $628 \mathrm{bp}$ fragment of the mitochondrial cytochrome $c$ oxidase subunit I (COI) gene was amplified with a 1:1 mixture of two forward primers, bcdF08 and bcdF09 (Kolicka et al. 2016), and reverse primer bcdR04 (Dabert et al. 2010). A fragment coding for both internal transcribed spacers (ITS1-5.8S rDNAITS2) was amplified with ITS1_18S and ITS2_28S primers (Navajas et al. 1998). A complete sequence of $18 \mathrm{~S}$ rRNA was amplified in two overlapping fragments using $18 \mathrm{Sfw} / \mathrm{rev} 960$ and fw390/rev18S primer pairs (Dabert et al. 2010), respectively. A 2381 bp fragment of 28S rRNA was amplified using the primer pair 28SF0001/28SR2850 (Dabert et al. 2016). For primer details see Table 2. PCRs were carried out in $10 \mu 1$ reaction volumes containing $5 \mu 1$ of the Type-it Microsatellite PCR Kit (Qiagen), $0.5 \mu \mathrm{M}$ of each primer and $4 \mu \mathrm{l}$ of the DNA template using a thermocycling profile with one cycle 
Table 1. Main results of sediment sample granulometric analyses. All measurements are given in micrometres $(\mu \mathrm{m})$; indicators are given as a percentage $(\%)$ and italicized.

\begin{tabular}{lccccc}
\hline Sites & & $\mathbf{1}$ & $\mathbf{2}$ & $\mathbf{3}$ & $\mathbf{4}$ \\
\hline Mean & & Coarse sand & Very coarse sand & Medium sand & Very coarse sand \\
& $\left(\mathrm{M}_{\mathrm{G}}\right)$ & 859.5 & 1235.8 & 384.2 & 1318.4 \\
\multirow{2}{*}{ Sorting } & & Moderately sorted & Well sorted & Poorly sorted & Very well sorted \\
& $\left(\sigma_{\mathrm{G}}\right)$ & 1.748 & 1.277 & 2.190 & 1.071 \\
Skewness & & Symmetrical & Very fine skewed & Fine skewed & Very coarsely skewed \\
& & -0.016 & -2.521 & -0.104 & 1.076 \\
Kurtosis & Mesokurtic & Very fine skewed & Leptokurtic & Very platykurtic \\
& 1.080 & 1.069 & 1.131 & -0.596 \\
\multicolumn{2}{l}{ Organic matter } & 6.61 & 2.64 & 4.09 & 2.63 \\
\hline
\end{tabular}

of $5 \mathrm{~min}$ at $95^{\circ} \mathrm{C}$ followed by 40 steps of $30 \mathrm{~s}$ at $95^{\circ} \mathrm{C}, 90 \mathrm{~s}$ at $50^{\circ} \mathrm{C}, 1 \mathrm{~min}$ at $72^{\circ} \mathrm{C}$, and with a final step of $5 \mathrm{~min}$ at $72^{\circ} \mathrm{C}$ for all reactions. After amplification, the PCR products were diluted with $10 \mu 1$ of MQ water; $5 \mu 1$ of the diluted PCR reaction was analysed by electrophoresis on $1 \%$ agarose gel. Samples containing visible bands were purified with exonuclease I and Fast alkaline phosphatase (Fermentas) and sequenced using the BigDye Terminator v3.1 kit and the ABI Prism 3130xl Genetic Analyzer (Applied Biosystems), following the manufacturer's instructions. Individual sequence reads were aligned and manually assembled into contigs in ChromasPro v. 1.32 (Technelysium) and GeneDoc v. 2.7.000 (Nicholas \& Nicholas 1997). Genetic distance among the COI sequences was estimated using the Kimura 2-parameter model as implemented in MEGA 7 (Kimura 1980; Tamura et al. 2013).

\section{Phylogenetic analyses}

The nucleotide blast search of COI, $18 \mathrm{~S}$ and 28S rRNA sequences of Chaetonotus (Chaetonotus) antrumus sp. nov. suggested Chaetonotus sp. 1 (in Kånneby, Todaro \& Jondelius 2013), Chaetonotus (Chaetonotus) cf. sphagnophilus Kisielewski, 1981 and Chaetonotus (Chaetonotus) cf. laroides Marcolango, 1910 as the most similar taxa. Therefore, in our phylogenetic analyses we used representatives of the main clades reconstructed in the published molecular phylogeny of Chaetonotidae (Kånneby et al. 2013; Kolicka et al. 2016). As the outgroup we used sequences of Aspidiophorus polystictos Balsamo \& Todaro, 1987, which has been reconstructed as the sister group to all other species of Chaetonotidae by Kånneby et al. (2013). In total, our data set consisted of 4881 nucleotide positions for 55 terminals (Table 3 ) and involved COI $+18 \mathrm{~S}+28 \mathrm{~S}$ markers. ITS sequences were excluded from the data set because of the lack of sequence data for this marker for most species included in the phylogenetic analysis.

Choice of an appropriate model of DNA sequence evolution for 18S and 28S rDNA was made using jModeltest 0.11 (Posada 2008); the GTR + I + G model was appropriate for both markers. For COI DNA sequences the two-rate codon-based model was applied (Goldman \& Yang 1994) with invertebrate mtDNA genetic code. Tree inference was performed using Bayesian Inference with Markov Chain Monte Carlo (BI), with the appropriate substitution model for each partition. Four independent chains were run on a parallel version of MrBayes 3.2 (Ronquist et al. 2012). Each run of the BI analyses was performed in $3-10 \times 10^{6}$ generations, and the trees were sampled every $1000^{\text {th }}$ generation. The final $50 \%$ majority rule consensus tree was generated after discarding the $25 \%$ burn-in fraction of initial trees after assessing the chain convergence in Tracer v.1. (Rambaut \& Drummond 2007) judged by the average standard deviation of split frequencies dropping below 0.01 . Tree editing was performed using FigTree 1.4.2 (Rambaut 2014). 
Table 2. PCR primers used in this study; A and S refer to amplifying and sequencing, respectively.

\begin{tabular}{|c|c|c|c|c|}
\hline Primer name & Sequence $\left(5^{\prime}-3^{\prime}\right)$ & Product & Use & Source \\
\hline bcdF08 & CGATGRTTTTTTTCHACWAACCAYAARGATATCGG & COI & A & Kolicka et al. 2016 \\
\hline bcdF09 & CGATGRTTTTTTTCHACWAACCAYAARGACATTGG & COI & A, $S$ & Kolicka et al. 2016 \\
\hline bcdR04 & TATAAACYTCDGGATGNCCAAAAAA & COI & $\mathrm{A}, \mathrm{S}$ & Dabert et al. 2008 \\
\hline ITS1_18S & AGAGGAAGTAAAAGTCGTAACAAG & ITS & $\mathrm{A}, \mathrm{S}$ & Navajas et al. 1998 \\
\hline ITS2_28S & ATATGCTTAAATTCAGGGGG & ITS & $\mathrm{A}, \mathrm{S}$ & Navajas et al. 1998 \\
\hline $18 \mathrm{Sfw}$ & CTTGTCTCAAAGATTAAGCCATGCA & $18 \mathrm{~S}$ rDNA & $\mathrm{A}, \mathrm{S}$ & Dabert et al. 2010 \\
\hline rev480 & GTTATTTTTCGTCACTACCT & 18S rDNA & $\mathrm{S}$ & Dabert et al. 2010 \\
\hline fw390 & AATCAGGGTTCGATTCCGGAGA & 18S rDNA & $\mathrm{A}, \mathrm{S}$ & Dabert et al. 2010 \\
\hline rev960 & GACGGTCCAAGAATTTCAC & $18 \mathrm{~S}$ rDNA & $\mathrm{A}, \mathrm{S}$ & Dabert et al. 2010 \\
\hline for 1300 & TGCATGGCCGTTCTTAGTTG & 18S rDNA & S & Dabert et al. 2010 \\
\hline rev1460 & CATCACAGACCTGTTATTGC & $18 \mathrm{~S}$ rDNA & S & Dabert et al. 2010 \\
\hline rev18S & TGATCCTTCCGCAGGTTCACCT & 18S rDNA & $\mathrm{A}, \mathrm{S}$ & Dabert et al. 2010 \\
\hline 28SF0001 & ACCCVCYNAATTTAAGCATAT & 28S rDNA & A & Dabert et al. 2016 \\
\hline 1634LReverse & e ATTCGGCAGGTGAGTTGTTACA & $28 \mathrm{~S}$ rDNA & $\mathrm{S}$ & Telford et al. 2003 \\
\hline $1200 \mathrm{~F}$ & CCCGAAAGATGGTGAACTATGC & 28S rDNA & S & Telford et al. 2003 \\
\hline $2450 \mathrm{R}$ & GCTTTGTTTTAATTAGACAGTCGGA & 28S rDNA & $\mathrm{A}, \mathrm{S}$ & Telford et al. 2003 \\
\hline 28SR2850 & GTGGTTTCGCTAGATAGTAGATA & 28S rDNA & $\mathrm{A}, \mathrm{S}$ & Dabert et al. 2016 \\
\hline $300 \mathrm{~F}$ & CAAGTACCGTGAGGGAAAGTTG & 28S rDNA & $\mathrm{S}$ & Telford et al. 2003 \\
\hline $300 \mathrm{R}$ & CAACTTTCCCTCACGGTACTTG & $28 \mathrm{~S}$ rDNA & $\mathrm{S}$ & Telford et al. 2003 \\
\hline $1200 \mathrm{R}$ & GCATAGTTCACCATCTTTCGG & $28 \mathrm{~S}$ rDNA & S & Telford et al. 2003 \\
\hline UJR2176 & CGGATCTAATTTGCCGACTTCCCTTA & $28 \mathrm{~S}$ rDNA & $\mathrm{S}$ & Telford et al. 2003 \\
\hline $1600 \mathrm{~F}$ & AGCAGGACGGTGGCCATGGAAG & $28 \mathrm{~S}$ rDNA & $\mathrm{S}$ & Telford et al. 2003 \\
\hline
\end{tabular}

\section{Results}

Gastrotrichs, belonging to only one species, were present in two of the four sampled sites: Site 1 (9 specimens) and Site 3 (27 specimens) in Fig. 2.

The physicochemical parameters of the water on the investigated cave river did not vary between sampling sites and were the following: temperature: $12^{\circ} \mathrm{C}$; conductivity: $3.18 \mu \mathrm{S} / \mathrm{cm}$; dissolved oxygen: $10.66 \mathrm{mg} / \mathrm{dm}^{3}$; biochemical oxygen demand over 5 days $\left(\mathrm{BOD}_{5}\right): 1.98 ; \mathrm{NO}_{3}:<0.10 \mathrm{mg} / \mathrm{dm}^{3}$; $\mathrm{NH}_{4}$ concentration: $0.207 \mathrm{mg} / \mathrm{dm}^{3} ; \mathrm{PO}_{3}$ concentration: $0.170 \mathrm{mg} / \mathrm{dm}^{3}$. The granulometry varied among sites (Table 1). Sites 1 and 3 had a high organic content with moderately to poorly sorted fine sediments, while Sites 2 and 4 had lower organic content and more coarse sands. In addition to Gastrotricha in the examined material, we found protozoa (mainly Ciliata), nematodes and rotifers (Bdelloidea as well as Monogononta). 
Table 3. DNA sequences of the gastrotrichs species used in phylogenetic analysis.

\begin{tabular}{|c|c|c|c|}
\hline \multirow{2}{*}{ Species } & \multicolumn{3}{|c|}{ GenBank acc. nos. } \\
\hline & $18 S$ & 28S & COI \\
\hline Arenotus strixinoi & JQ798537 & JQ798608 & JQ798677 \\
\hline Aspidiophorus ophiodermus & JN185463 & JN185510 & - \\
\hline Aspidiophorus polystictos & JQ798597 & JQ798664 & JQ798726 \\
\hline Aspidiophorus tetrachaetus & JN185505 & JN185540 & JN185576 \\
\hline Bifidochaetus arcticus & KP713403 & KP713404 & KP713405 \\
\hline Chaetonotus sp. Kånneby, Todaro \& Jondelius, 2013 & JQ798555 & - & JQ798692 \\
\hline Chaetonotus sp. 1 Kånneby, Todaro \& Jondelius, 2013 & JQ798601 & JQ798668 & JQ798730 \\
\hline Chaetonotus (Chaetonotus) antrumus Kolicka sp. nov. & KX538804 & KU705232 & KU705230 \\
\hline Chaetonotus (Chaetonotus) daphnes & JQ798549 & JQ798617 & JQ798687 \\
\hline Chaetonotus (Chaetonotus) cf. sphagnophilus & JQ798604 & JQ798671 & JQ798733 \\
\hline Chaetonotus (Chaetonotus) cf. laroides & JQ798602 & JQ798669 & JQ798731 \\
\hline Chaetonotus (Chaetonotus) microchaetus & JQ798575 & JQ798618 & JQ798684 \\
\hline Chaetonotus (Chaetonotus) cf. similis & JQ798592 & JQ798660 & JQ798722 \\
\hline Chaetonotus (Chaetonotus) similis & JQ798578 & JQ798648 & JQ798710 \\
\hline Chaetonotus (Chaetonotus) polyspinosus & JQ798563 & JQ798654 & JQ798717 \\
\hline Chaetonotus (Chaetonotus) maximus 1 & JQ798577 & - & JQ798709 \\
\hline Chaetonotus (Chaetonotus) maximus 2 & JQ798574 & JQ798646 & JQ798706 \\
\hline Chaetonotus (Primochaetus) armatus & JQ798594 & - & JQ798723 \\
\hline Chaetonotus (Primochaetus) acanthocephalus & JQ798569 & - & JQ798701 \\
\hline Chaetonotus (Primochaetus) acanthodes 1 & JQ798544 & JQ798616 & JQ798682 \\
\hline Chaetonotus (Primochaetus) acanthodes 2 & JQ798552 & JQ798624 & - \\
\hline Chaetonotus (Primochaetus) heideri 1 & JQ798547 & JQ798619 & JQ798685 \\
\hline Chaetonotus (Primochaetus) heideri 2 & JQ798590 & JQ798657 & JQ798720 \\
\hline Chaetonotus (Hystricochaetonotus) hystrix 1 & JQ798557 & JQ798627 & - \\
\hline Chaetonotus (Hystricochaetonotus) hystrix 2 & JQ798603 & JQ798670 & JQ798732 \\
\hline Chaetonotus (Hystricochaetonotus) cf. novenarius & JQ798566 & JQ798636 & JQ798699 \\
\hline Chaetonotus (Marinochaetus) mariae & JQ798558 & JQ798628 & - \\
\hline Chaetonotus (Schizochaetonotus) dispar & JQ798561 & JQ798631 & JQ798696 \\
\hline Chaetonotus (Schizochaetonotus) neptuni 1 & JQ798539 & JQ798610 & JQ798679 \\
\hline Chaetonotus (Schizochaetonotus) neptuni 2 & JQ798595 & JQ798662 & JQ798724 \\
\hline Chaetonotus (Schizochaetonotus) schultzei & JQ798596 & JQ798663 & JQ798725 \\
\hline Chaetonotus (Wolterecka) uncinus & JQ798540 & JQ798611 & - \\
\hline Chaetonotus (Zonochaeta) bisacer & JQ798565 & JQ798635 & - \\
\hline Halichaetonotus euromarinus & JQ798551 & JQ798623 & - \\
\hline Halichaetonotus sp. 1 Kånneby, Todaro \& Jondelius, 2013 & JQ798600 & JQ798667 & JQ798729 \\
\hline Halichaetonotus sp. 2 Kånneby, Todaro \& Jondelius, 2013 & JQ798560 & JQ798630 & JQ798695 \\
\hline Halichaetonotus aculifer & JQ798550 & JQ798622 & JQ798688 \\
\hline Halichaetonotus paradoxus & JQ798599 & JQ798666 & JQ798728 \\
\hline Heterolepidoderma loricatum & JQ798541 & JQ798612 & - \\
\hline Heterolepidoderma macrops & JN185469 & JN185515 & JN185548 \\
\hline Heterolepidoderma ocellatum & JN185475 & JN185519 & JN185554 \\
\hline Heterolepidoderma sp. & JQ798554 & - & JQ798691 \\
\hline Ichthydium (Furficulichthys) skandicum & JQ798573 & JQ798645 & JQ798705 \\
\hline Lepidochaetus brasilense 1 & JN185458 & JN185507 & JQ798680 \\
\hline Lepidochaetus brasilense 2 & JN185495 & JQ798658 & JN185568 \\
\hline Lepidochaetus zelinkai & JN185486 & JN185527 & JN185564 \\
\hline Lepidodermella intermedia & JN185468 & JN185514 & JN185547 \\
\hline Lepidodermella minor minor & JN185474 & - & JN185553 \\
\hline Polymerurus nodicaudus 1 & JN185460 & - & JN185542 \\
\hline Polymerurus nodicaudus 2 & JN185502 & JN185537 & JN185573 \\
\hline Polymerurus nodicaudus 3 & JN185465 & JN185512 & JQ798689 \\
\hline Polymerurus nodicaudus 4 & JN185473 & JQ798642 & JN185552 \\
\hline Polymerurus rhomboides 1 & JQ798584 & - & JQ798715 \\
\hline Polymerurus rhomboides 2 & JN185467 & JN185513 & JN185546 \\
\hline Polymerurus rhomboides 3 & JN185493 & JN185533 & JN185567 \\
\hline
\end{tabular}




\title{
Taxonomic account
}

\author{
Phylum Gastrotricha Mečnikow, 1865 \\ Order Chaetonotida Remane, 1925 [Rao \& Clausen 1970] \\ Suborder Paucitubulatina d'Hondt, 1971 \\ Family Chaetonotidae Gosse, 1864 (sensu Leasi \& Todaro 2008) \\ Subfamily Chaetonotinae Gosse, 1864 (sensu Kisielewski 1991)
}

Genus Chaetonotus Ehrenberg, 1830

\section{Type species}

Chaetonotus larus (Müller, 1773).

\section{Type area}

Denmark.

Subgenus Chaetonotus sensu stricto Ehrenberg, 1830

\section{Type species}

Chaetonotus larus (Müller, 1773).

\section{Type area}

Denmark.

Chaetonotus (Chaetonotus) antrumus Kolicka sp. nov. urn:lsid:zoobank.org:act:BF874601-C073-465F-B50B-48D73DB5A4C5

Figs 4-11; Table 4; Appendix

\section{Diagnosis}

Slender body, length from 91.2 to $129.7 \mu \mathrm{m}$. Head five-lobed, cephalion and pleuria weakly marked in the head outline. Hypostomium small and rhomboidal. Ocellar granules absent. Scales small, threelobed and with strong keels. One pair of one-lobed, keeled scales on the dorsal side of the posterior part of the trunk, and on the dorsal and dorsolateral sides of the furcal appendages. Two pairs of three-lobed, spined scales present on the ventral side of the furcal appendages. Scales distributed in 29-35 total longitudinal rows $(11-13 \mathrm{D}+6-8 \mathrm{DL}+6 \mathrm{~L}+4-6 \mathrm{LV}+2 \mathrm{~V})$ with $23-27$ scales in the central row, and differing morphologically in the areas of the head, neck and trunk, respectively. Spines thick, simple, with blunt ends. Spine lengths strongly vary: spines of the head are longer than those of the neck; spines of the neck are short, but become progressively longer to the widest body region, after which they gradually shorten towards the furcal base. The spines gradually increase in length from lateral to ventral body side towards the ciliary bands. Ventral scale spines longer than the others and hair-like. Last pair of parafurcal spines longer and stronger. Ventral interciliary field naked, except for the posterior trunk region. A pair of ventral terminal scales long, oval with shallow posterior notches, keeled and spineless. Pharynx narrow with two weakly marked dilatations. Straight intestine with a distinct, short anterior section appearing as a narrow band.

\section{Etymology}

From Latin 'antrum', cave, referring to the habitat where the species was found. 


\section{Material examined}

\section{Holotype}

MONTENEGRO: adult, Crnojevica River flowing in Obodska Cave, $42^{\circ} 21.118^{\prime} \mathrm{N}, 19^{\circ} 0.304^{\prime} \mathrm{E}$, sample 3 , sampling site 3, 29 Jul. 2015, Piotr Gadawski leg., determined by Małgorzata Kolicka (photomicrograph in the Natural History Collections, Adam Mickiewicz University, Poznan: NHC-GCCA-12-1-20/h).

\section{Paratypes}

MONTENEGRO: 31 adults, 2 subadults, 2 juveniles, Crnojevica River flowing in Obodska Cave, $42^{\circ} 21.118^{\prime} \mathrm{N}, 1^{\circ} 0.304^{\prime} \mathrm{E}$, samples 1 and 3, sampling sites 1 and 3, 29 Jul. 2015, Piotr Gadawski leg., determined by Małgorzata Kolicka (Natural History Collections, Adam Mickiewicz University, Poznan under accesing number: NHC-GCCA-12-21-50).

\section{Description}

This new species has a slender body. Its head is wider than the neck and separated from the trunk by a distinct neck constriction. The neck extends into the trunk, which gradually widens towards its widest region beyond its midpoint (ca U61), after which it gradually tapers towards a distinct furcal base at U84. The branches of the furca are set wide apart. The furcal indentation is V-shaped, and the adhesive tubes diverge posteriorly. They measure $10.1-11.3 \mu \mathrm{m}$, are straight and thin and do not taper towards their blunt ends (Figs 4-6).

The head is five-lobed and semi-circular. All plates are visible in the dorsal head outline. The cephalion (U1-U5) adheres to the head along its entire length, is narrow and widens at the dorsal edge. The epipleuria (U4-U6) are small and slightly convex. The hypopleuria (U7-U13) are more than twice as large as the epipleuria. The hypopleuria are not visible from the dorsal side; only their outline is marked in body shape (Figs 4A, 7). The hypostomium (U5-U8) is short and rhomboidal with slightly rounded edges and a strong anterior edge (Fig. 4C). Two pairs of cephalic ciliary tufts are present. The anterior tufts have four cilia each that emerge from between the cephalion and epipleuria and are arranged in lines around the lateral edges of the cephalion. The beginning of these lines (the first two cilia) is clearly visible on the dorsal side. The anteriormost cilium in both anterior tufts is fairly short (the shortest). The second cilium is longer than the first. The third cilium is very long and is the longest of all cilia in the tuft. The posteriormost cilium is shorter than the third and similar in length to the second cilium. The posterior tufts have five cilia each and emerge ventrally at the anterior edge of the hypopleuria. The length of the cephalic cilia in the posterior tufts increases from the anteriormost to the fourth cilium. The posteriormost cilium is similar in length to the first (see Appendix). Ocellar granules are not present. The mouth ring is narrow, located sub-terminally at U2-U3 and has weakly marked, granular reinforcements. Short inner hairs are present inside the mouth ring and suboral hairs are located around it.

The body is covered by small, three-lobed scales and single one-lobed scales that adhere over their entire surface to the cuticle (Figs 5-9). Scales are distributed in 29-35 total longitudinal and alternating rows $(11-13 \mathrm{D}+6-8 \mathrm{DL}+6 \mathrm{~L}+4-6 \mathrm{LV}+2 \mathrm{~V})$ with $23-27$ scales in the dorsal central row. Each scale has a strong keel and triangular with a deeply-notched posterior edge. On the head, neck and anterior and middle parts of the trunk, the longitudinal rows of scales run parallel to each other, while in the posterior part of the trunk and on the furcal base the scales gradually converge towards the central longitudinal row (Figs 4, 7-9). The scales on the head, neck and trunk are arranged close to one another, but their edges do not adhere or overlap. The longitudinal rows of scales begin on the head beyond the posterior edges of the cephalion, epipleuria and hypopleuria. The scales show a strong morphological diversity in posterolateral lobe distinctness, edge roundness and size throughout the different surfaces of the head, neck and trunk regions. On the head, there are deeply-notched, rounded, wide triangles with rounded posterolateral lobes that are weakly differentiated from the central lobe. On the neck, scales are narrower, and 
their postero-lateral lobes show a weaker separation from the central lobe (see Appendix; Figs 4A, 5). On the trunk, scales are shaped like narrow, deeply-notched triangles with their postero-lateral lobes clearly differentiated from the central lobe and with edges that are less rounded (Figs 4-5, 8A, C, E, 9A). The size of the scales decreases rapidly at the beginning of the neck, after which it gradually increases towards the beginning of the trunk (head: $1.6-3.8 \mu \mathrm{m}$ length $\times 1.8-4.3 \mu \mathrm{m}$ width vs neck: $1.3-3.3 \mu \mathrm{m}$ length $\times 1.4-3.9 \mu \mathrm{m}$ width vs trunk: $2.5-5.6 \mu \mathrm{m}$ length $\times 1.6-4.3 \mu \mathrm{m}$ width). The dorsal head and neck scales differ most from one another (Figs 4A, 5, 7A), whereas in the other areas of the head and neck, the differences in shape and size between the scales are gradual. The size of the scales of the trunk increases from the anterior end towards the widest trunk region, after which it decreases towards the furcal base (see Appendix). On the posterior part of the trunk, scales are clearly smaller than those at the widest point of the body. A fine (1.9-2.7 $\mu \mathrm{m}$ length $\times 1.3-1.8 \mu \mathrm{m}$ width) one-lobed, keeled and spineless scale is located at U78 on the dorsal part of the trunk, anterior to each scale bearing a sensory bristle (Figs 4A, 8C) and is shaped like a strongly-rounded triangle. Medially, on the dorsal side of the furcal appendages (U86-U88), three three-lobed scales are present that are slightly narrower than the other scales of the trunk (see Appendix; Figs 4A, 8G). Lateral to these scales, on the furcal appendages (U85-U88), there are two pairs of elongated one-lobed scales shaped like narrow ovals with a weakly-notched posterior edge. The anterior one of each pair of scales is located dorsally, has a strong keel and a long, straight spine, whereas the posterior one is located dorsolaterally and has a long keel, but no spine. The lateral edges of these scales are partially overlapping. On the lateral side of the furcal appendages (U86-U90), two pairs of three-lobed scales, of the same type as the scales of the trunk, with spines are present (Figs 6, 9A). The dorsal, dorsolateral, lateral, ventrolateral and ventral scales do not strongly vary in size, except that the scales in the area of the neck and in the longitudinal rows next to the ciliary bands are considerably smaller than the others. The ventral scales of the longitudinal rows located closest to the ventral ciliary bands are about half the size of the scales in the other rows (head: 1.6-2.9 $\mu \mathrm{m}$ length $\times$ 1.8-2.3 $\mu \mathrm{m}$ width; neck: $1.3-1.8 \mu \mathrm{m}$ length $\times 1.4-2.0 \mu \mathrm{m}$ width; trunk: $2.5-3.0 \mu \mathrm{m}$ length $\times 1.6-2.0$ $\mu \mathrm{m}$ width) and have their central lobe rotated about $20^{\circ}$ towards the bands (see Appendix; Figs $4 \mathrm{C}, 8 \mathrm{C}$, 10C).

The spines arising from the posterior scales region are thick and straight, taper very slightly towards their blunt ends and have no lateral denticles (Figs 4, 7B, D, 8B, D, F, 9B, 10E). The spines that adhere directly to the cephalion and pleuria are the shortest of the head spines (Fig. 7B). The spines on the head increase in length $(1.1-3.1 \mu \mathrm{m})$, whereas those on the neck decrease rapidly in length. The spines on the neck are much shorter than those in the head area; the spines are merely vestigial halfway down the neck, after which they gradually lengthen towards the trunk $(0.5-2.7 \mu \mathrm{m})$ (Figs 4, 7B). The spines on the trunk gradually and slightly lengthen from the beginning of the trunk (ca U30) up to the widest body region (ca U61), after which they gradually shorten towards the furcal base at U84 $(1.3-4.1 \mu \mathrm{m})$ (Figs 4, 8B, D, F). The pair of posteriormost lateral trunk spines is slightly longer and thicker than the surrounding spines $(3.4-5.9 \mu \mathrm{m})$. Parafurcal spines emerging from two lateral scales per side on the furcal appendages are slightly thicker and longer than the other spines of the body, the posteriormost pair is longer, thicker and stronger than those of the preceding pair (see Appendix; Fig. 4). These spines taper slightly towards their blunt distal ends. The dorsal and dorsolateral spines do not vary substantially in length (Table 4). The spines lengthen gradually and slightly from the lateral side towards the ciliary bands (Fig. 9B). The spines arising from the ventral longitudinal row of scales located closest to the ciliary bands are much longer than those of the body, curved, and hair-like along their entire length (head: 5.1-8.6 $\mu \mathrm{m}$; neck: 5.0-9.0 $\mu \mathrm{m}$; trunk: 7.1-14.0 $\mu \mathrm{m}$ ).

This species has three pairs of dorsal sensory bristles (Fig. 4). The first pair is located on the head, directly posterior to the cephalion, near the lateral edges of the epipleuria (U5), and each bristle emerges from a small, round papilla. The second pair is located on the neck (U25) and each bristle emerges from a small, rounded papilla. The third, posterior pair, which emerges from double-keeled scales located in 

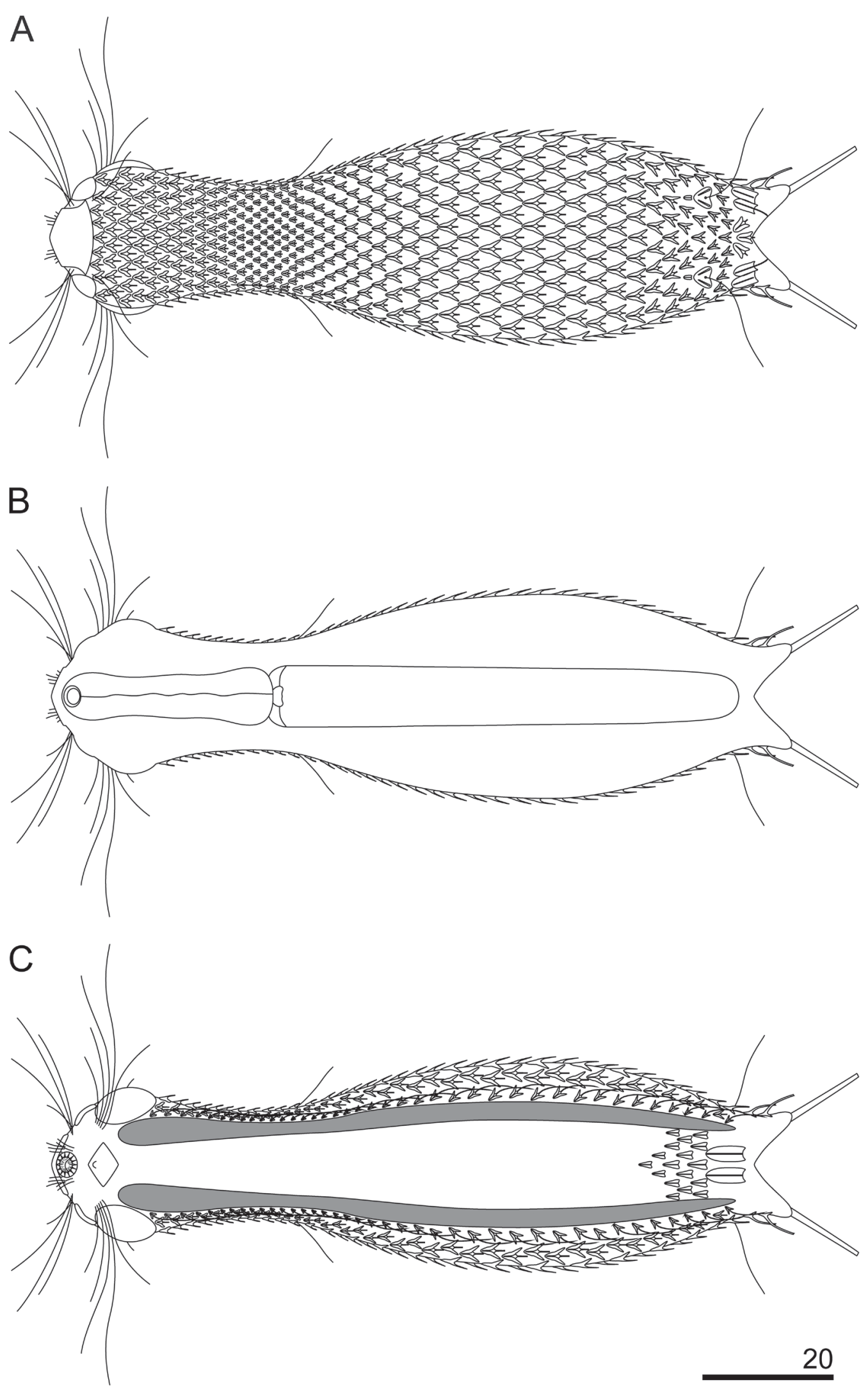

Fig. 4. Chaetonotus (Chaetonotus) antrumus Kolicka sp. nov., schematic drawings. A. Dorsal body view. B. Internal body view. C. Ventral body view. 
A

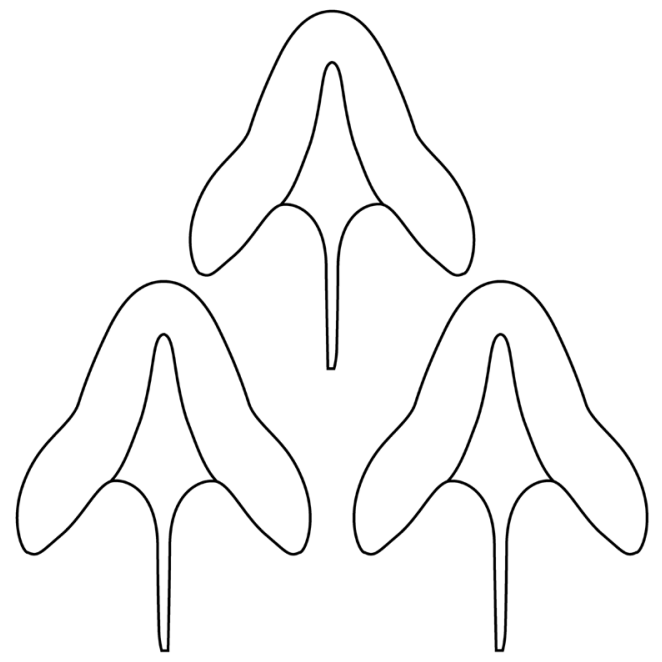

B

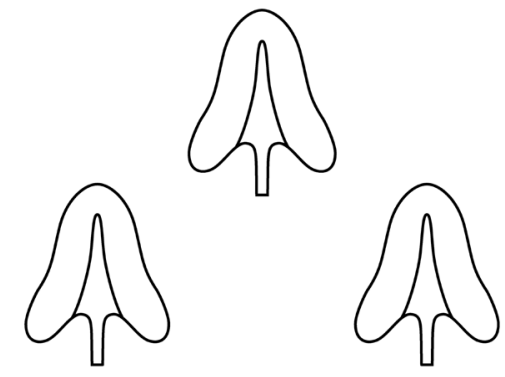

C

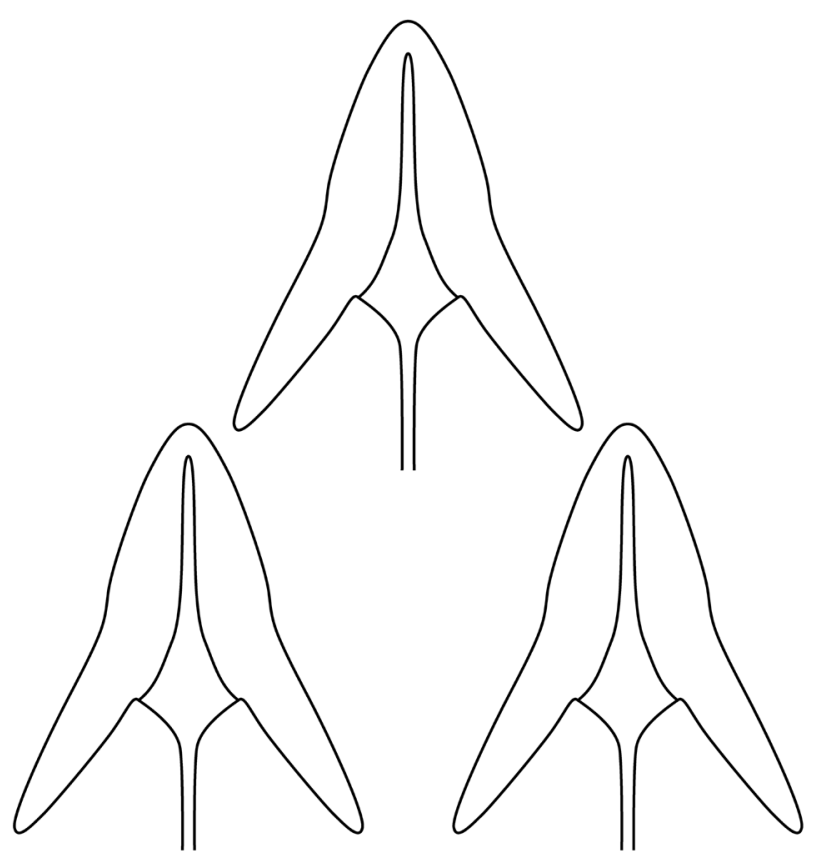

$\mathrm{D}$

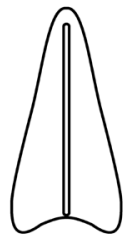

$\mathrm{E}$

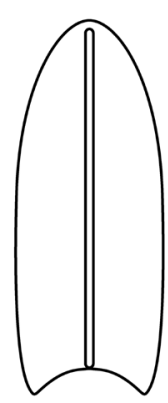

$\mathrm{F}$

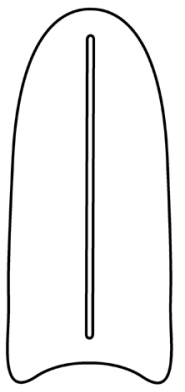

G

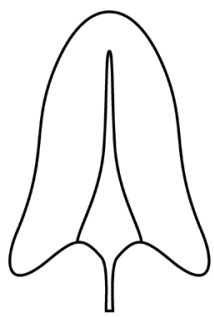

$\mathrm{H}$

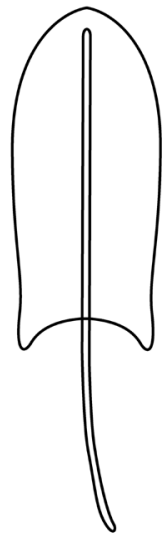

Fig. 5. Chaetonotus (Chaetonotus) antrumus Kolicka sp. nov., schematic drawings of the scales. A. Head region scales. B. Neck region scales. C. Trunk region scales. D. Ventral interciliary field scales. E. Posteriormost ventral field scales. F, H. Furcal appendages dorsolateral one-lobed scales. G. Furcal appendages dorsal three-lobed scales. 
the posterior part of the trunk (U79-U80), is shaped like deeply-notched triangles with unconnected keels (Figs 4A, 5).

On the ventral side, the longitudinal ciliary bands begin at U8 and run back to U84 (Fig. 4C). They are wider in the area of the head than in the other parts of the body. Most of the ventral interciliary field is naked: fine, keeled, spined scales are present only in the posterior part of the trunk (from ca U78 to U82) (Figs 4C, 8H). Their differentiation increases towards the posterior body region: the anterior scales are weakly delineated and partially submerged in the cuticle. These scales are shaped like narrow triangles with a very weakly notched posterior edge. The scales of the ventral interciliary field increase in size towards the posterior end of the body (1.4-3.7 $\mu \mathrm{m}$ length $\times 1.1-1.9 \mu \mathrm{m}$ width). The terminal scales are located at U82-U85 and are shaped like long, narrow ovals with a very weakly notched posterior edge and have a long keel running along their entire length, but are spineless (Figs 4C, 5E).

The pharynx (U2-U28) is relatively narrow and has weak anterior and posterior dilatations, with the posterior dilatation wider than the anterior one (Figs 4B, 7C; Appendix). The pharynx connects through the small and narrow pharyngeal intestinal junction (U30) to a straight intestine (running from U29 to U86). The intestine has a distinct, short (U29-U31) anterior section marked as a narrow band (Fig. 4B).

\section{Remarks}

Chaetonotus (Chaetonotus) antrumus sp. nov. is an interstitial species which was recorded in the lotic system in a cave. The gastrotrich fauna in interstitial freshwater habitats is relatively rich, but composed

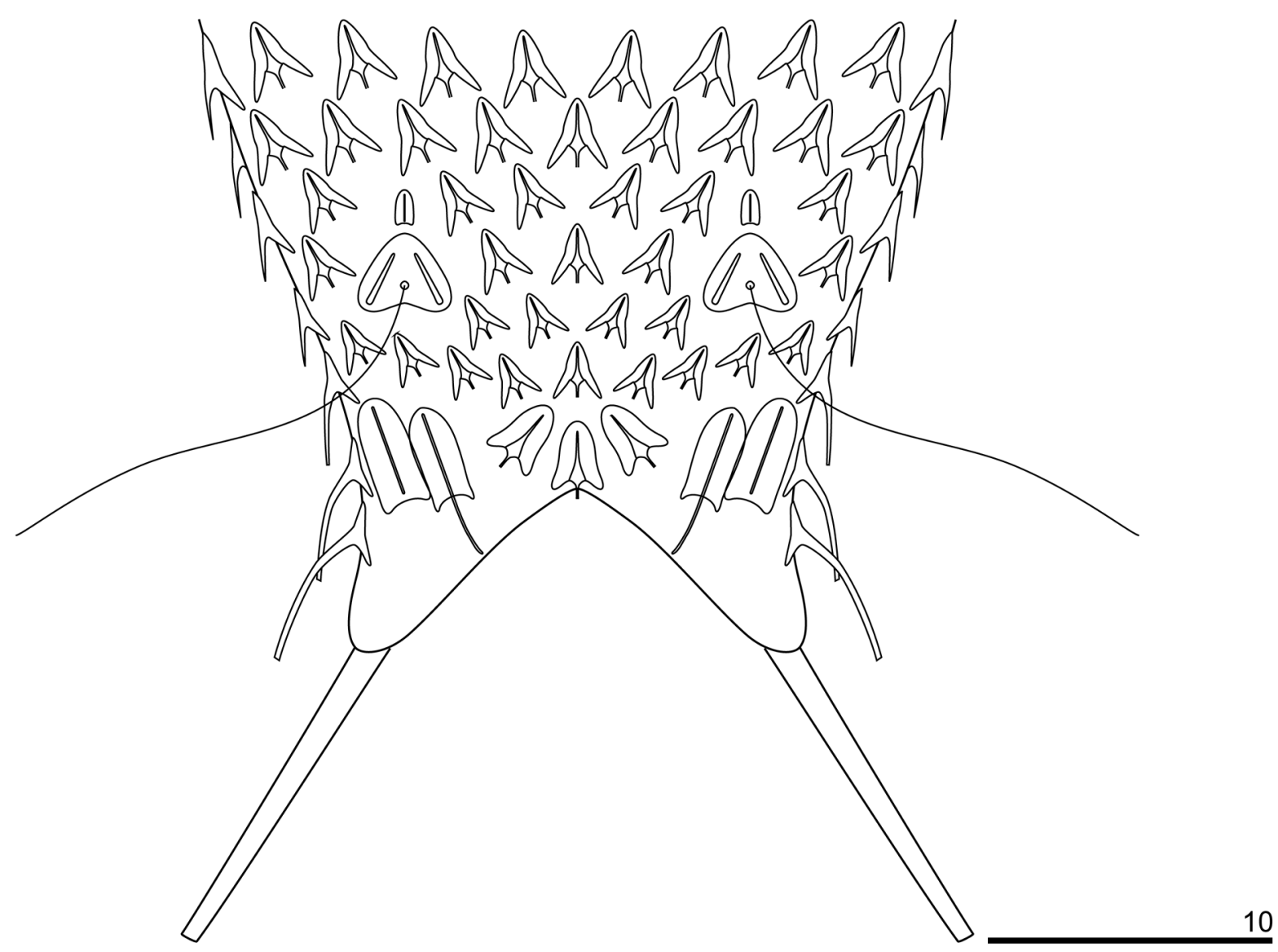

Fig. 6. Chaetonotus (Chaetonotus) antrumus Kolicka sp. nov., schematic drawings of the posterior trunk region, furcal base and furcal appendages. 


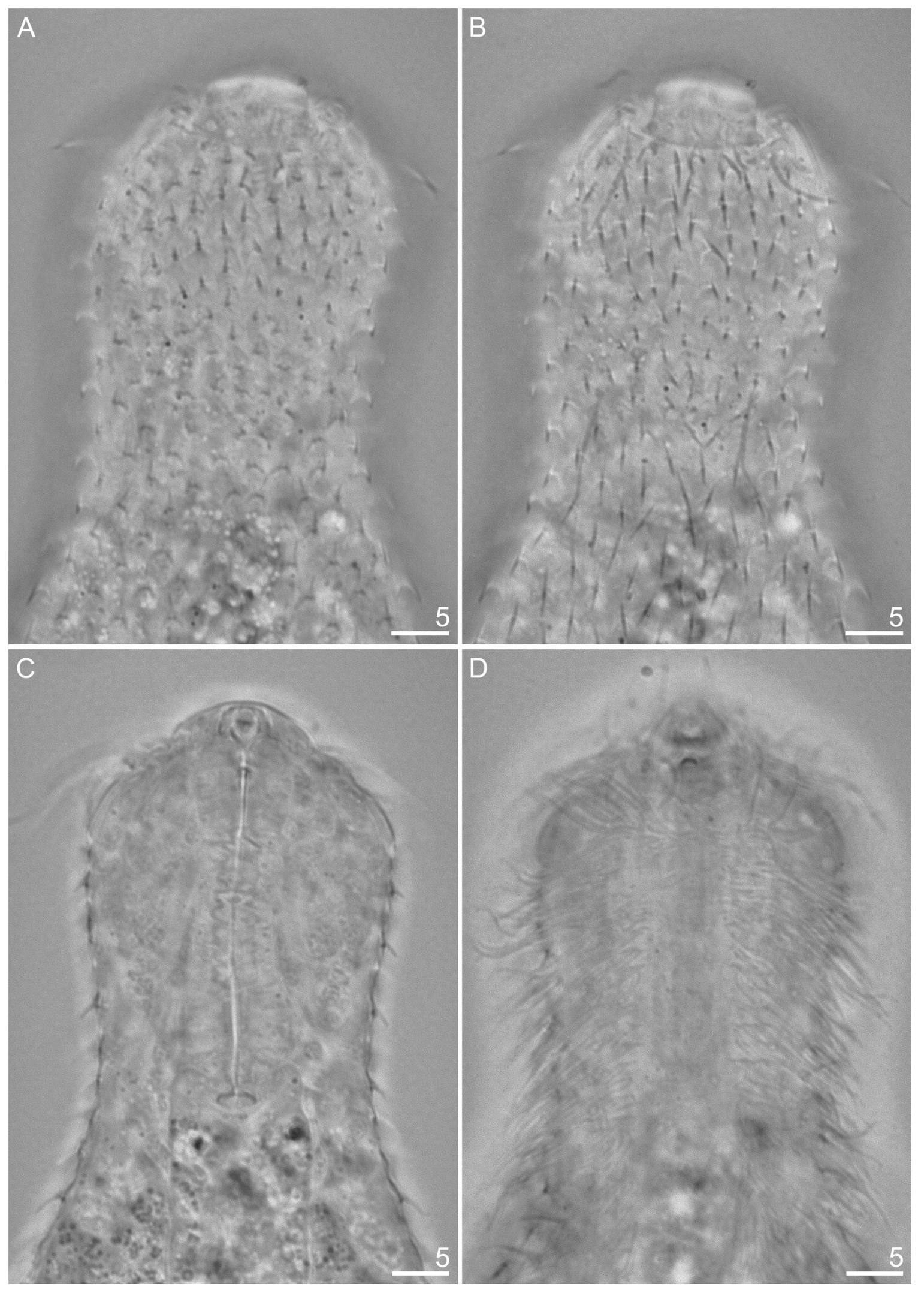

Fig. 7. Chaetonotus (Chaetonotus) antrumus Kolicka sp. nov. A. Dorsal view of scales on head and neck. B. Dorsal view of spines on head and neck. C. Internal view of head and neck. D. Head and neck, ventral view. (Bright field microphotographs.) 


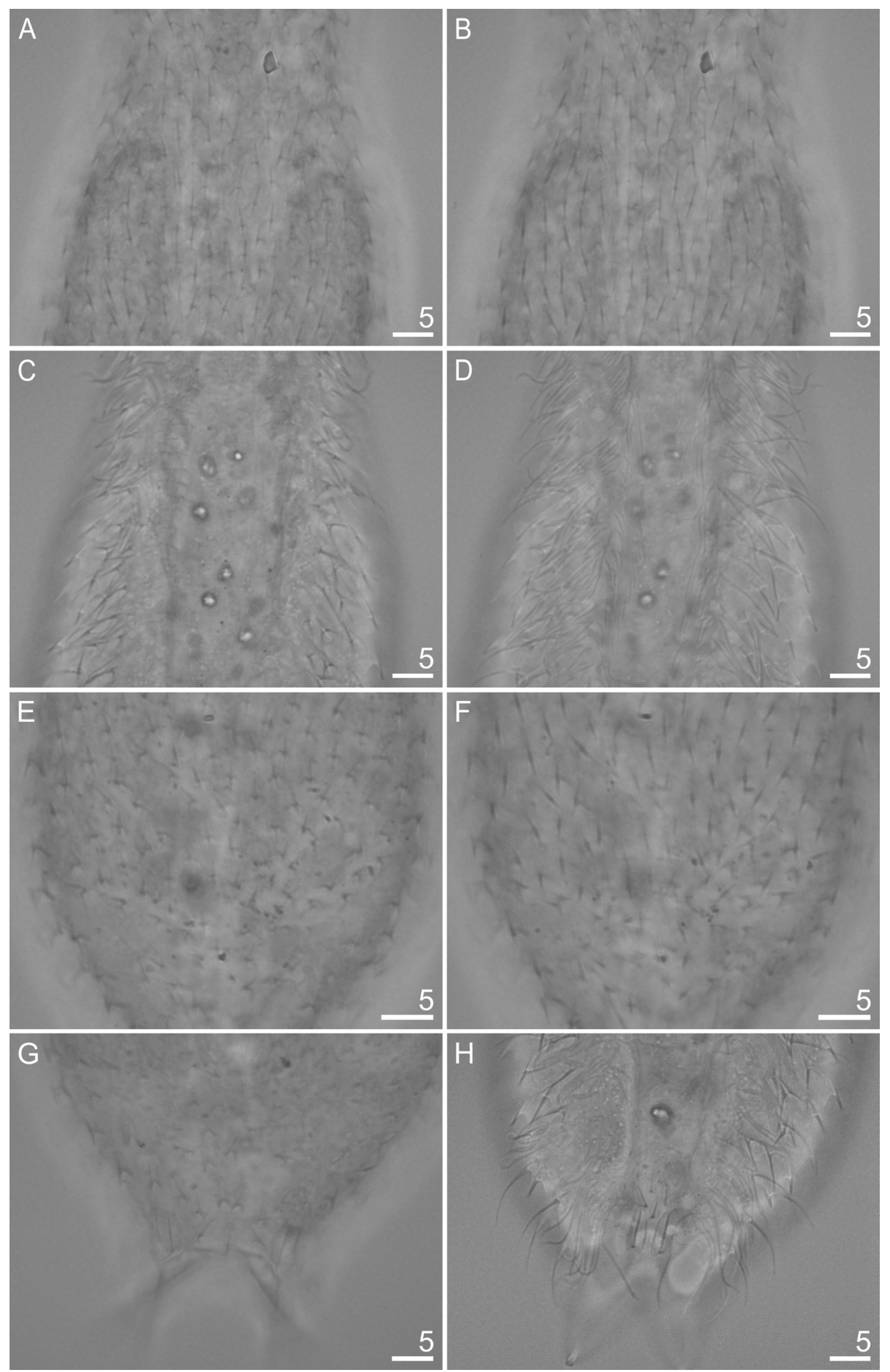

Fig. 8. Chaetonotus (Chaetonotus) antrumus Kolicka sp. nov., bright field microphotographs. A. Dorsal view of scales on trunk region. B. Dorsal view of spines on trunk region. C. Ventral view of scales on trunk region. D. Ventral view of spines on trunk region. E. Dorsal view of scales on posterior trunk region. F. Dorsal view of spines on posterior trunk region. G. Dorsal view of scales on furcal base and furcal appendages. H. Ventral view of posterior trunk region with visible interciliary field scales and posteriormost interciliary field scales. 


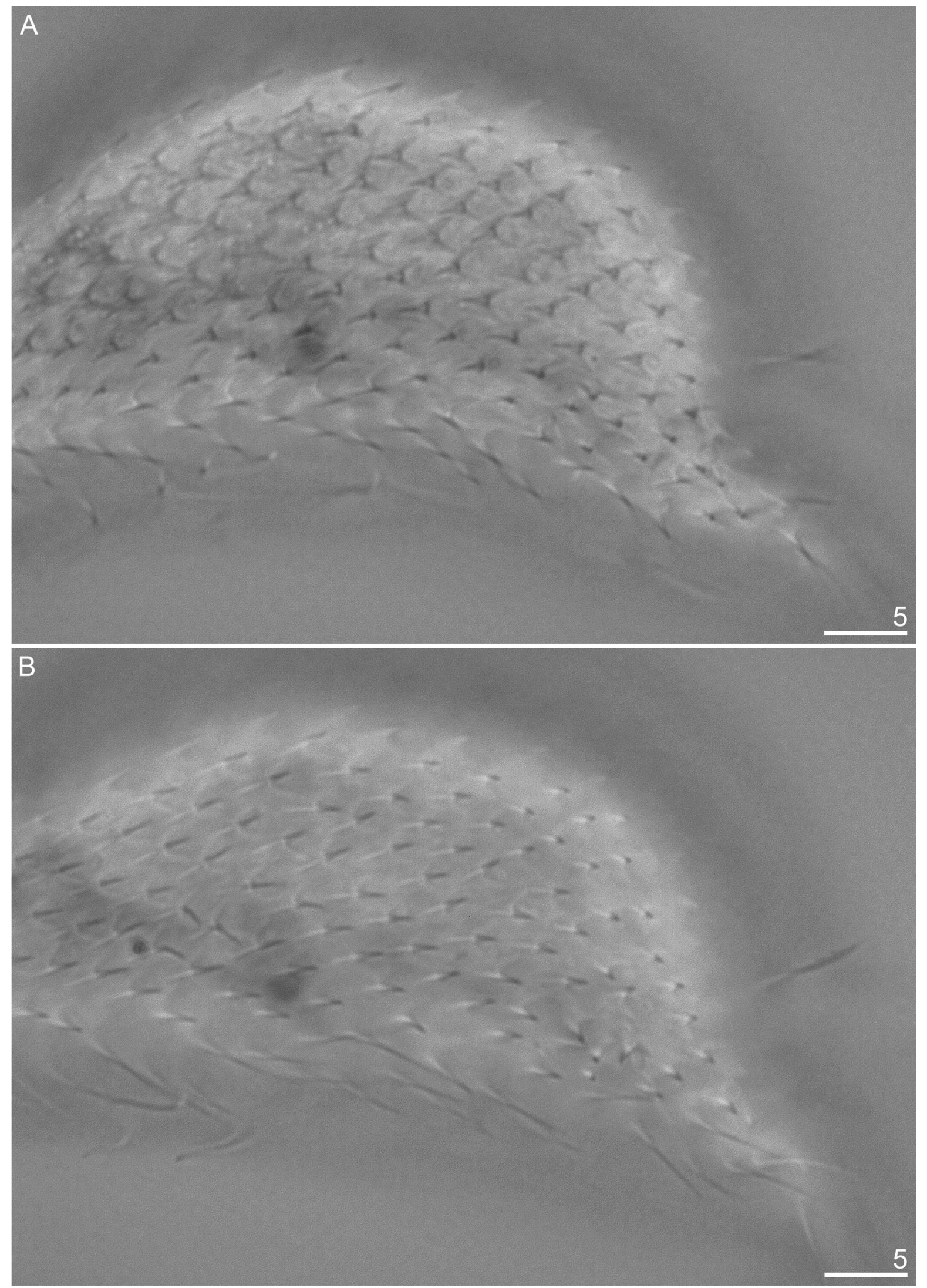

Fig. 9. Chaetonotus (Chaetonotus) antrumus Kolicka sp. nov., bright field microphotographs. A. Lateral view of scales on trunk. B. Lateral view of spines on trunk. 


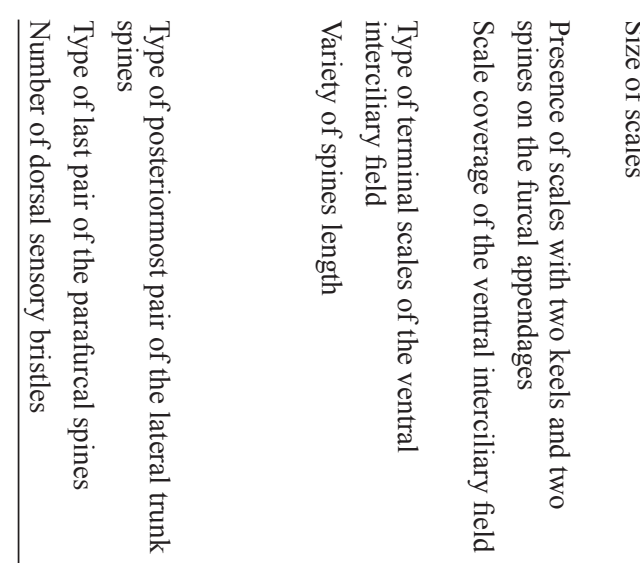

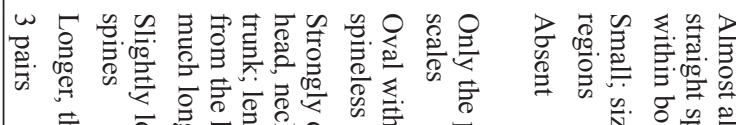

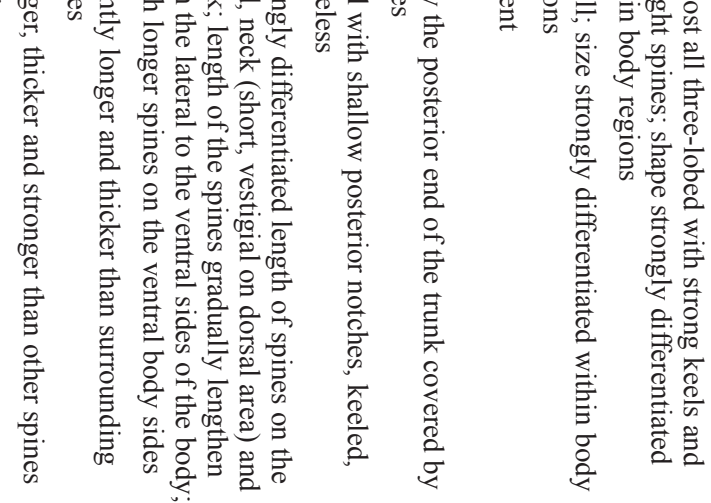

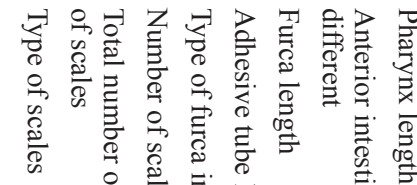
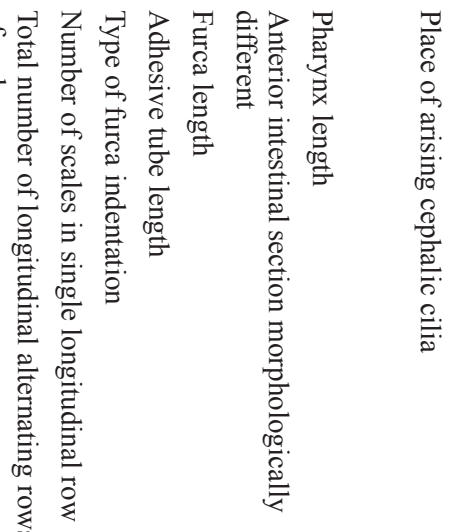

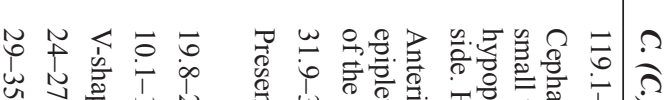

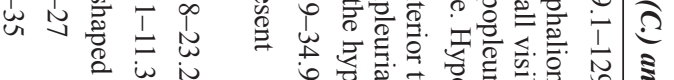

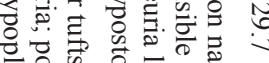

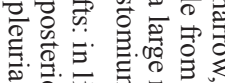

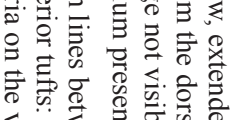

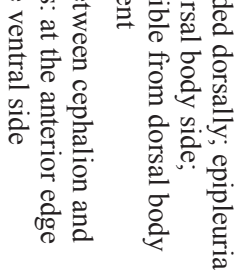

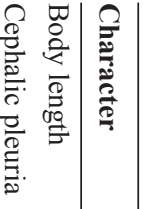

중 불 $\frac{0}{5}+\frac{0}{\circ}$ if

完 3

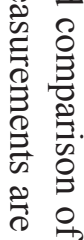
皇. 泉.

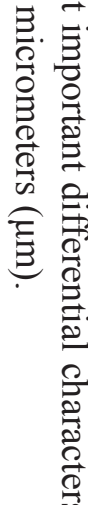

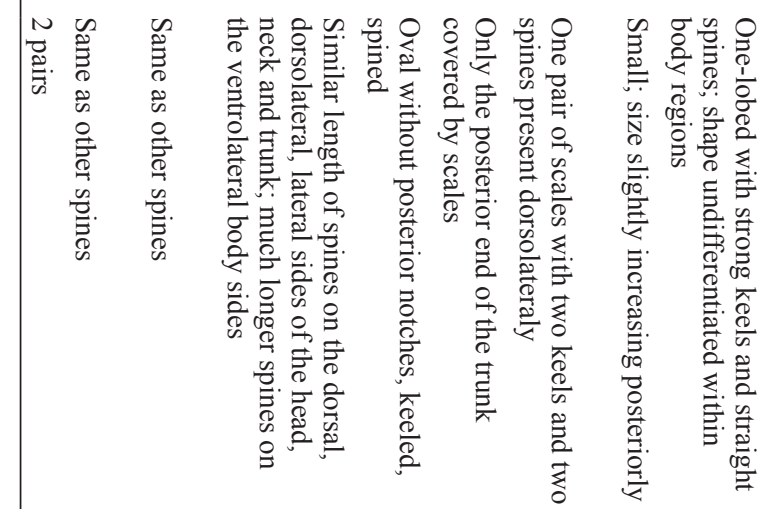

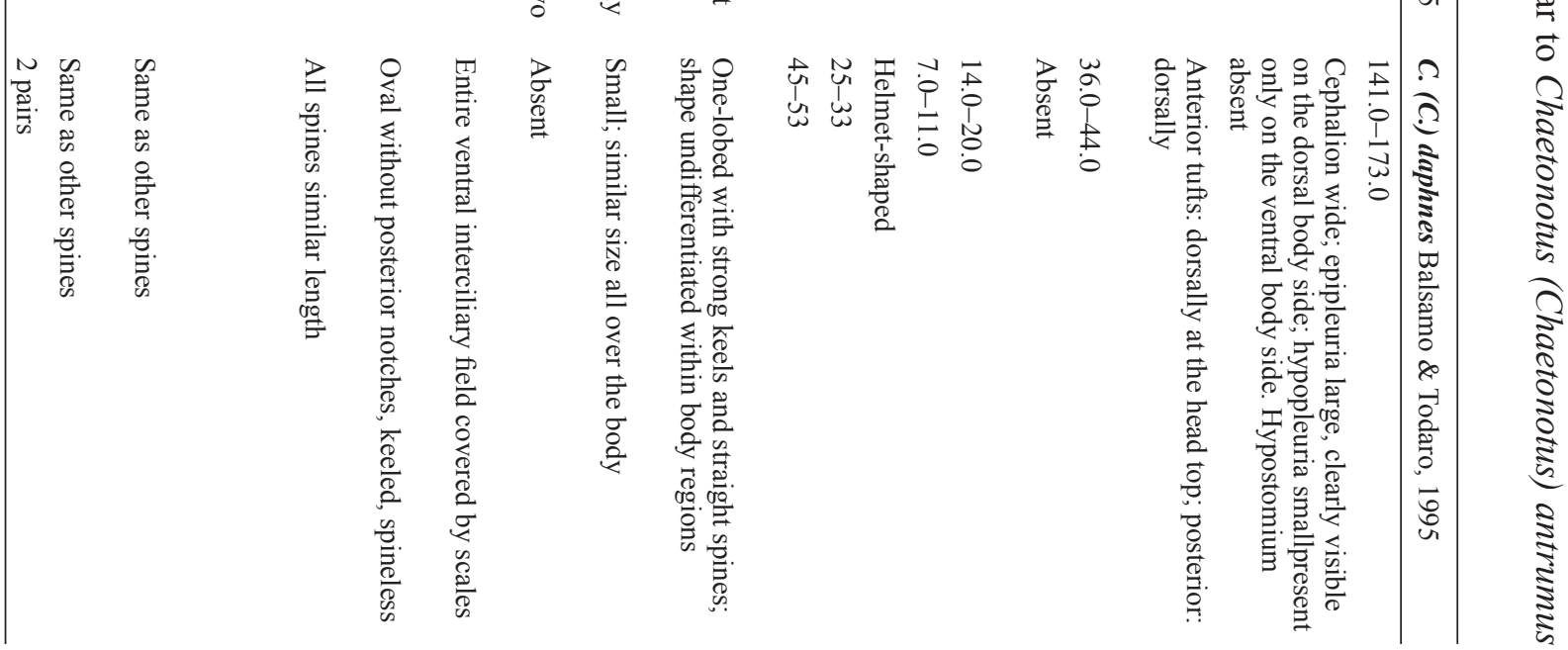



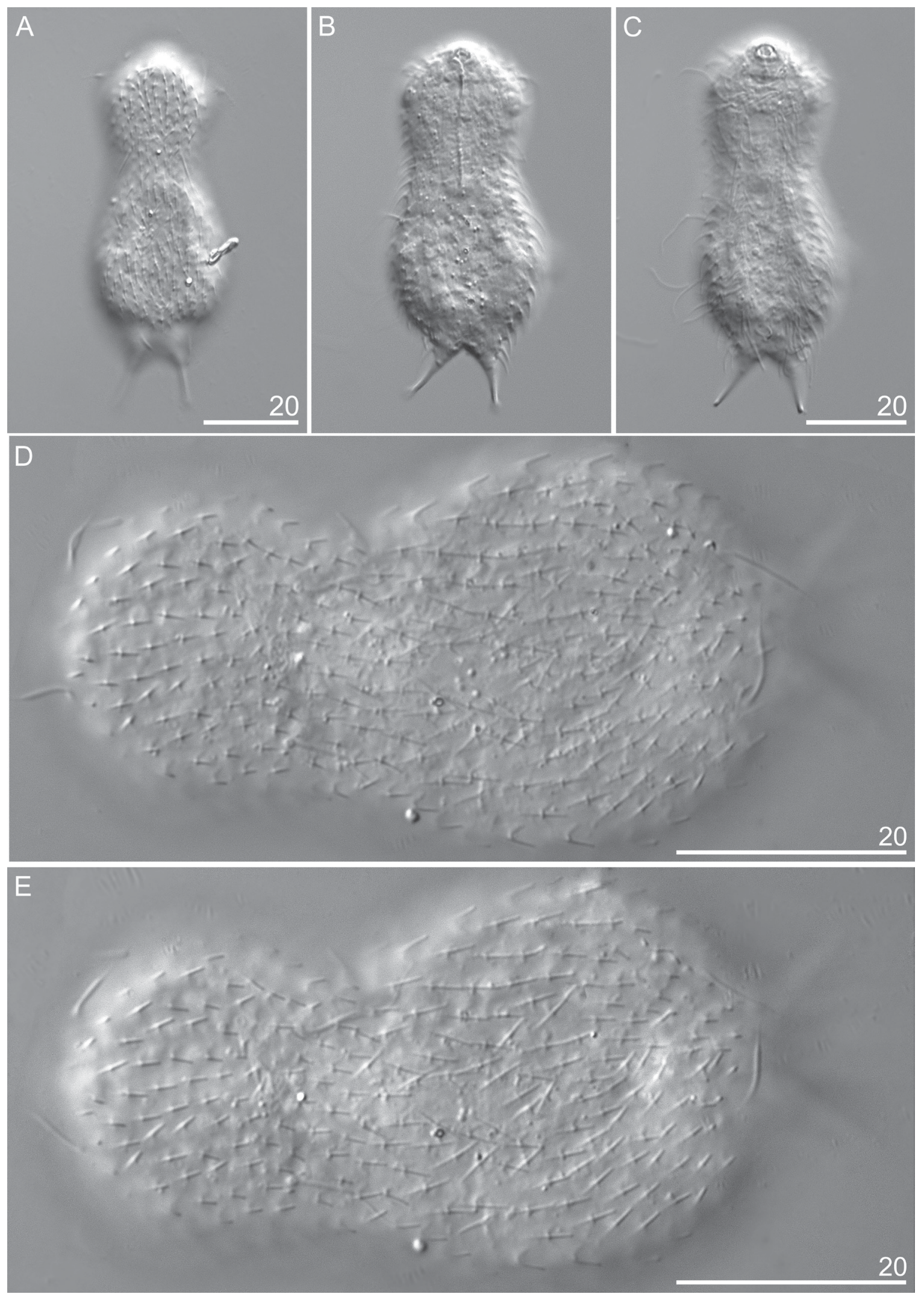

Fig. 10. Chaetonotus (Chaetonotus) antrumus Kolicka sp. nov., juvenile specimen, differential interference contrast microphotographs. A. Body, dorsal view. B. Body, internal view. C. Ventral body view. D. Dorsal view of scales. E. Dorsal view of spines. 
of fewer species than in epibenthic or periphytic habitats (e.g., Balsamo et al. 2015). Interstitial communities are composed of not only taxa specific to them, but also of eurytopic species. Out of ca 40 species found in sandy biotopes, fewer than 10 seem to constitute exclusively interstitial taxa (Balsamo et al. 2015). All of the species share certain morphological traits, e.g., a small body size, a poorly ornamented cuticular covering, a well developed locomotory ciliature and adhesive organs (Balsamo \& Fregni 1995; Balsamo et al. 2015). Entire sets of these characteristics also occur in C. (C.) antrumus sp. nov.

Usually, one or two pairs of sensory bristles have been described in Chaetonotidae, but in C. (C.) antrumus sp. nov., three pairs of dorsal sensory bristles are present. The presence of dorsal sensory bristles in the area of the head has previously been noted in only two species of Chaetonotus: C. (C.) brevispinosus Zelinka, 1889 and C. (C.) sanctipauli Kisielewski, 1991. Perhaps three pairs of dorsal sensory bristles occur more frequently in Chaetonotidae; the location of the first pair of dorsal sensory bristles on the head near the cephalion and the cephalic cilia, however, may have led to these sensory bristles being

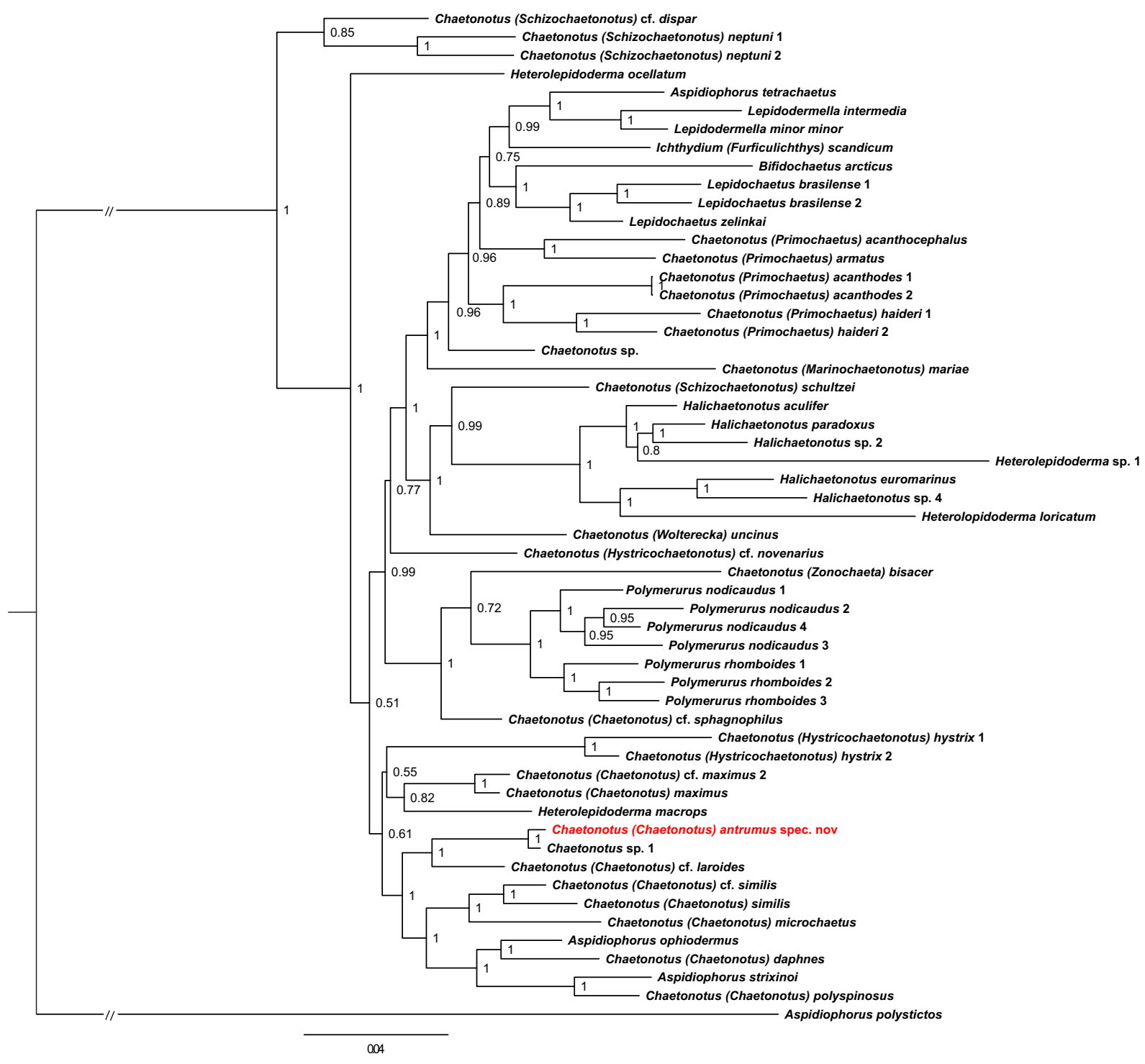

Fig. 11. Phylogenetic relationships of Chaetonotidae inferred from the Bayesian analysis of $18 \mathrm{~S}$ rRNA, $28 \mathrm{~S}$ rRNA and COI sequence data (for details on the species names see Table 3 ). 
obscured by the cilia or erroneously interpreted as one of the cilia. Thus, the presence of dorsal sensory bristles on the head cannot be considered as a good diagnostic characters at the species level.

The presence of a developing egg was observed in 21 out of 32 adult specimens of C. (C.) antrumus sp. nov. However, sperm and an X-organ were not observed.

Chaetonotus (Chaetonotus) antrumus sp. nov. showed very quick locomotion under microscopic observation. The species often remained in motion even after its integument had burst from compression under a cover glass, thus producing a visible deformation.

\section{Sequence diversity and phylogenetic relationships}

The COI alignment for the distance calculations comprised 628 bp of unambiguous sequence data for three specimens of Chaetonotus (Chaetonotus) antrumus sp. nov. We found two haplotypes that differed in eight nucleotide positions ( $\mathrm{K} 2 \mathrm{P}=0.013$; $\mathrm{SD}=0.005)$. All substitutions were located at synonymous sites, i.e., both haplotypes coded for the same amino acid sequence. The nuclear data, including 4809bp of the DNA region coding for 18S rRNA, ITS1, 5.8S, ITS2, and 28S rRNA, showed no intraspecific variation. All sequences are deposited in GenBank under accession numbers KU705230, KU705231 (COI); KX538804 (18S); KU705232 (28S); KU705233 (ITS).

A phylogenetic analysis (Fig. 11) recovered, with maximum support, C. (C.) antrumus sp. nov. as closely related to the undetermined Chaetonotus sp. 1 TK-2012 (Kånneby et al. 2013); both grouped with C. (C.) cf. laroides. This clade was in a sister relation to a clade consisting of some representatives of Chaetonotus (Chaetonotus) Ehrenberg, 1830 and Aspidiophorus (Voigt, 1903) and including Chatonotus (Chaetonotus) daphnes Balsamo \& Todaro, 1995, which is morphologically most similar to the new species.

\section{Differential diagnosis}

Even if the new species was recorded from a sandy habitat, it is not similar to any other species considered as exclusively interstitial taxa. Chaetonotus Ehrenberg, 1830 is a polyphyletic genus, containing varied species. Of all the 165 currently known nominal freshwater representatives of this genus, C.(C.) antrumus sp. nov. is morphologically closest to C. (C.) naiadis Balsamo \& Todaro, 1995 and $C$. (C.) daphnes Balsamo \& Todaro, 1995, both of which were originally reported from Italian mountain pools. These two species were selected from all the Chaetonotus representatives for the comparison of the new species due to a similarity in terms of (1) the alignment of scales whose edges are juxtaposed; the presence of a different type of scales on the dorsal and dorsolateral sides of the furcal base; (2) the type of scales on the ventral interciliary field; (3) the number of terminal scales of the ventral interciliary field; (4) two longitudinal bands of ventral locomotor cilia wider on the head region. Despite the fact that from all of the hitherto known species, $C$. (C.) naiadis and $C$. (C.) daphnes have the highest number of common features with the newly described species, they are significantly different from $C$. (C.) antrumus sp. nov., most strikingly in the scale type and shape. All the differences between the new species and the most morphologically similar taxa have been summarized in Table 4 .

\section{Discussion}

The presence of Chaetonotus (Chaetonotus) antrumus sp. nov. in only two of four sampling sites may reflect the habitat selectivity by the species. The species was observed only in the samples with a high organic matter content, a minimum diameter spectra of the sand grain, and moderately to poorly sorted sediments. This result confirms previous observations regarding the habitat preferences of many freshwater gastrotrichs, which appear to prefer finer sediments with high organic matter content (e.g., Kisielewski 1997; Balsamo \& Todaro 2002; Balsamo et al. 2014). However, the occurrence and 
composition of the Gastrotricha fauna inhabiting caves may depend not only on the physicochemical habitat properties (temperature, sunlight, granulometry of the sediments, the water flow rate) (e.g., Balsamo et al. 2014), but also on the possibility of colonization and food availability. Gastrotrichs, as other meiobenthic invertebrates, have limited locomotory abilities. Dispersal in freshwater gastrotrichs is probably limited to migration through aquatic sediments and dispersal of resistant eggs (see below).

The result of our molecular phylogenetic analysis is for the greater part congruent with the previous molecular phylogenies of Chaetonotidae (Kånneby et al. 2013; Kolicka et al. 2016) and gave further evidence to the high degree of polyphyletism of chaetonotid genera. Freshwater species of the order Chaetonotida, which may produce opsiblastic, resting eggs, are known for passive migration with water currents, watercourses, surface run-offs, wind and being carried by more mobile animals, e.g., birds, bats, amphibians, insects or annelids (e.g., Gerlach 1977; Kolicka et al. 2014). One of those vectors was most probably responsible for the transport of gastrotrichs into Obodska Cave. Because of their wide range of ecological tolerance and parthenogenetic reproduction, Gastrotricha may have persisted there and developed a population. When analyzing the fauna of cave ecosystems, it must be remembered that those habitats are not influenced by sunlight. Thus, there are no photoautotrophs and the ecosystem is based mainly on the influx of organic matter from outside the cave. Most of the currently known species of Gastrotricha feed on bacteria, detritus, and small algae (e.g., Bennett 1979; Balsamo \& Todaro 2002; Todaro \& Hummon 2008). The lack of unicellular autotrophs may not be a limiting factor for the majority of Gastrotricha species that feed mainly on bacteria (e.g., Balsamo et al. 2014).

Further studies will show whether Chaetonotus (Chaetonotus) antrumus sp. nov. is endemic to Obodska Cave, or more widely distributed and not associated with only one specific type of environment. The application of methods typical for integrative taxonomy (i.e., combined morphological, morphometric and molecular analyses), will allow verification of future reports regarding the presence of this species and accurate determination of its biogeography.

\section{Acknowledgements}

We would like to thank James Kirk for his invaluable comments on the draft version of the manuscript. The authors wish to thank two anonymous reviewers for their helpful comments. Special thanks to Małgorzata Kuźnik for figures of the new species used in this paper. Last but not least, we are grateful to Lech Kotwicki for help with the granulometric analysis, to Krzysztof Pabis for his helpful advise to this paper, and to Katarzyna Gadawska, Aleksandra Bańkowska, Magdalena Kłosowska, Grzegorz Michoński and Przemysław Śmietana for their help during the research expedition.

\section{References}

Balsamo M. \& Fregni E. 1995. Gastrotrichs from interstitial fresh water, with a description of four new species. Hydrobiologia 302: 163-175. https://doi.org/10.1007/BF00027040

Balsamo M. \& Todaro M.A. 2002. Gastrotricha. In: Rundle S.D., Robertson A.L. \& Schmid-Araya J.M. (eds) Freshwater Meiofauna: Biology and Ecology: 45-61. Backhuys Publishers, Leiden.

Balsamo M., Grilli P., Guidi L. \& d'Hondt J.-L. 2014. Gastrotricha: biology, ecology and systematics: families Dasydytidae, Dichaeturidae, Neogosseidae, Proichthydiidae. In: Dumont H.J.F. (ed.) Identification Guides to the Plankton and Benthos of Inland Waters 24. Backhuys Publishers and Margraf Publishers, Weikersheim.

Balsamo M., d'Hondt J.-L., Kisielewski J. \& Pierboni L. 2008. Global diversity of gastrotrichs (Gastrotricha) in fresh waters. Hydrobiologia 595: 85-91. https://doi.org/10.1007/978-1-4020-8259-7_10 
Balsamo M., d'Hondt J.-L., Kisielewski J., Todaro M.A., Tongiorgi P., Guidi L., Grilli P. \& de Jong Y. 2015. Fauna Europea: Gastrotricha. Biodiversity Data Journal 3: e5800. https://doi.org/10.3897/BDJ.3.e5800

Balsamo M., d'Hondt J.-L., Pierboni L. \& Grilli P. 2009. Taxonomic and nomenclatural notes on freshwater Gastrotricha. Zootaxa 2158: 1-19.

Bennett L.W. 1979. Experimental analysis of the trophic ecology of Lepidodermella squamata (Gastrotricha: Chaetonotida) in mixed culture. Transactions of the American Microscopy Society 98: 254-260.

Blott S. \& Pye K. 2001. Gradistat: a grain size distribution and statistics package for the analysis of unconsolidated sediments. Earth Surface Processes and Landforms 26: 1237-1248. https://doi.org/10.1002/esp.261

Bonada N., Rieradevall M., Dallas H., Davis J., Day J., Figueroa R., Resh V.H. \& Prat N. 2008. Multiscale assessment of macroinvertebrate richness and composition in Mediterranean-climate rivers. Freshwater Biology 53: 772-788. https://doi.org/10.1111/j.1365-2427.2007.01940.x

Buchanan J.B. 1984. Sediment analysis. In: Holme N.A. \& McIntyre A.D. (eds) Methods for the Study of Marine Benthos: 41-65. Blackwell Scientific Publications, Boston, MA.

Dabert J., Ehrnsberger R. \& Dabert M. 2008. Glaucalges tytonis sp. nov. (Analgoidea: Xolalgidae) from the barn owl Tyto alba (Strigiformes: Tytonidae): compiling morphology with DNA barcode data for taxa descriptions in mites (Acari). Zootaxa 1719: 41-52.

Dabert M., Proctor H.C. \& Dabert J. 2016. Higher-level molecular phylogeny of the water mites (Acariformes: Prostigmata: Parasitengonina: Hydrachnidiae). Molecular Phylogenetics and Evolution 101: 75-90. https://doi.org/10.1016/j.ympev.2016.05.004

Dabert M., Witalinski W., Kaźmierski A., Olszanowski Z. \& Dabert J. 2010. Molecular phylogeny of acariform mites (Acari, Arachnida): strong conflict between phylogenetic signal and long branch attraction artifacts. Molecular Phylogenetics and Evolution 56: 222-241. https://doi.org/10.1016/j.ympev.2009.12.020

Danovaro R. 1996. Detritus-bacteria-meiofauna interactions in a seagrass bed (Posidonia oceanica) of the NW Mediterranean. Marine Biology 127: 1-13. https://doi.org/10.1007/BF00993638

Danovaro R., Corinaldesi C., Filippini M., Fischer U.R., Gessner M.O., Jacquet S., Magagnini M. \& Velimirov B. 2008. Viriobenthos in freshwater and marine sediments: a review. Freshwater Biology 53: 1186-1213. https://doi.org/10.1111/j.1365-2427.2008.01961.x

Danovaro R., Luna G.M., Dell’ Anno A. \& Pietrangeli B. 2007. Measuring species richness based on microbial community fingerprints: the emperor has no clothes. Applied and Environmental Microbiology 73: 2399-2401. https://doi.org/10.1128/AEM.02383-06

d'Hondt J.-L. 1971. Gastrotricha. In: Barnes H. (ed.) Oceanography and Marine Biology: an Annual Review 9: 141-192. George Allen and Unwin Ltd, London.

Dinić J.B. 1965. Crnojevićka Pecina, in Nase Jame. Bohinec V. \& Savnik R. (eds), Ljubljana.

Doderović M., Bulić Z. \& Mijanović D. 2013. Turistička valorizacija speološkog potencijala cetinjske subregije tourist valorization of caving in Cetinje. Ćlovjek I krś 2014, Sarajevo.

Folk R.L. \& Ward W.C. 1957. Brazos River bar: a study in the significance of grain size parameters. Journal of Sedimentary Research 27: 3-26.

https://doi.org/10.1306/74D70646-2B21-11D7-8648000102C1865D 
Fraschetti S., Gambi C., Giangrande A., Musco L., Terlizzi A. \& Danovaro R. 2006. Structural and functional response of meiofauna rocky assemblages exposed to sewage pollution. Marine Pollution Bulletin 52: 540-548. https://doi.org/10.1016/j.marpolbul.2005.10.001

Gerlach S. 1977. Means of meiofauna dispersal. Mikrofauna Meeresboden 61: 89-103.

Giere O. 2009. Meiobenthology. The Microscopic Fauna in Aquatic Sediments. Springer Verlag, Berlin.

Goldman N. \& Yang Z. 1994. A codon-based model of nucleotide substitution for protein-coding DNA sequences. Molecular Biology and Evolution 11: 725-736.

Hou Z. \& Sket B. 2015. A review of Gammaridae (Crustacea: Amphipoda): the family extent, its evolutionary history, and taxonomic redefinition of genera. Zoological Journal of the Linnean Society 176 (2): 323-348. https://doi.org/10.1111/zoj.12318

Hummon W.D., Balsamo M. \& Todaro M.A. 1992. Italian marine Gastrotricha: I. Six new and one redescribed species of Chaetonotida. Bollettino di Zoologia 59: 499-516. https://doi.org/10.1080/11250009209386711

Hummon W.D. \& Todaro M.A. 2010. Analytic taxonomy and notes on marine, brackish-water and estuarine Gastrotricha. Zootaxa 2392: 1-32.

International Commission on Zoological Nomenclature 1999. International Code of Zoological Nomenclature, Fourth Edition. The International Trust for Zoological Nomenclature, The Natural History Museum, London.

Jones W.K., Hobbs H.H., Wicks C.M., Currie R.R., Hose L.D., Kerbo R.C., Goodbar J.R. \& Trout J. 2003. Recommendations and Guidelines for Managing Caves on Protected Lands. Karst Waters Institute Special Publication, Charles Town, West Virginia.

Kånneby T., Todaro M.A. \& Jondelius U. 2013. Phylogeny of Chaetonotidae and other Paucitubulatina (Gastrotricha: Chaetonotida) and colonization of aquatic ecosystems. Zoologica Scripta 42: 88-105. https://doi.org/10.1111/j.1463-6409.2012.00558.x

Kieneke A. \& Schmidt-Rhaesa A. 2015. Gastrotricha. In: Schmidt-Rhaesa A. (ed.) Handbook of Zoology. Gastrotricha and Gnathifera. Vol. 3. De Gruyter, Berlin/Boston.

Kimura M. 1980. A simple method for estimating evolutionary rate of base substitutions through comparative studies of nucleotide sequences. Journal of Molecular Evolution 16: 111-120. https://doi.org/10.1007/BF01731581

Kisielewski J. 1981. Gastrotricha from Raised and Transitional Peat Bogs in Poland. Monografie Fauny Polski, 11. Polska Akademia Nauk, Kraków.

Kisielewski J. 1991. Inland-water Gastrotricha from Brazil. Annales Zoologici 43: 1-168.

Kisielewski J. 1997. Brzuchorzeski (Gastrotricha). Fauna Stodkowodna Polski. Zeszyt31, Wydawnictwo Uniwersytetu Łódzkiego, Łódź.

Kolicka M. 2016. Gastrotrichs in bromeliads - newly recorded Chaetonotus (Hystricochaetonotus) furcatus Kisielewski, 1991 (Chaetonotida) from the Łódź Palm House. Zoosystema 38 (1): 141-155. https://doi.org/10.5252/z2016n1a5

Kolicka M., Dabert M., Dabert J., Kånneby T. \& Kisielewski J. 2016. Bifidochaetus: a new Arctic genus of freshwater Chaetonotida (Gastrotricha) from Spitsbergen revealed by the integrative taxonomy approach. Invertebrate Systematics 30: 398-419. https://doi.org/10.1071/IS16001

Kolicka M., Jankowska E. \& Kotwicki L. 2015. Baltic Sea Gastrotricha - one new species and one new record of Chaetonotida from Poland. Zootaxa 4027: 487-508. https://doi.org/10.11646/zootaxa.4027.4.2 
Kolicka M., Kisielewski J., Kotwicki L., Zawierucha K. \& Grzelak K. 2014. Checklist of Gastrotricha of the Polish Baltic Sea with the first reports of Heterolepidoderma joermungandri Kånneby, 2011, and Turbanella hyalina Schultze, 1853. Zootaxa 3869 (2): 101-130. https://doi.org/10.11646/zootaxa.3869.2.1

Kolicka M., Kisielewski J., Nesteruk T. \& Zawierucha K. 2013. Gastrotricha from the Poznań Palm House - one new subgenus and three new species of freshwater Chaetonotida (Gastrotricha). Zootaxa 3717 (2): 231-279. https://doi.org/10.11646/zootaxa.3717.2.7

Leasi F. \& Todaro M.A. 2008. The muscular system of Musellifer delamarei (Renaud-Mornant, 1968) and other chaetonotidans with implications for the phylogeny and systematization of the Paucitubulatina (Gastrotricha). Biological Journal of the Linnean Society 94: 379-398. https://doi.org/10.1111/j.1095-8312.2008.00974.x

Lješević A.M. 1968. Izveštaj o speleološkim istraživanjima Lipske pećine, (elaborat) u okviru projekta "Hidrogeologija sliva Skadarskog jezera, Zavod za geološka istraživanja CG”. Titograd.

Lješević A.M. 1969. Izveštaj o speleološkim istraživanjima Cetinjske pećine, Zavod za geološka istraživanja CG. Titograd.

Martel E.A. 1893. Les abîmes: les eaux souterraines, les cavernes, les sources, la speleology: explorations souterraines effectuées de 1888 à 1893 en France, Belgique, Autriche et Grèce. Charles Delagrave, Paris.

Martinović D. 1964. Cetinjsko polje (fizičko - geografska ispitivanja). Glasnik Srpskog Geografskog Društva 44: 27-37.

McCall J.N. \& Fleeger J.W. 1995. Predation by juvenile fish on hyperbenthic meiofauna, a review with data on post-larval Lelostomus xanthurus. Vie et Milieu 45: 61-73.

Mihavc A. 1983. Lipska in Začirska pečina, dve veliki Črnogorski jami. Published by Jamarska Zveza Slovenje, Speleological Associaton of Slovenia. Nase Jame 25: 37-39.

Navajas M., Lagnel J., Gutierrez J. \& Boursot P. 1998. Species-wide homogeneity of nuclear ribosomal ITS2 sequences in the spider mite Tetranychus urticae contrasts with extensive mitochondrial COI polymorphism. Heredity 80: 742-752.

Nicholas K.B. \& Nicholas H.B. 1997. GeneDoc: a Tool for Editing and Annotating Multiple Sequence Alignments. Distributed by the author.

Nozais C., Perissinotto R. \& Tita G. 2005. Seasonal dynamics of meiofauna in a South African temporarily open/closed estuary (Mdloti Estuary, Indian Ocean). Estuarine Coastal and Shelf 62: 325-338. https://doi.org/10.1016/j.ecss.2004.09.020

Palmer A.N. 1991. Origin and morphology of limestone caves. Vol. 103. Bulletin of the Geological Society of America 103 (1): 1-21.

Pešić V. 2010. Plagigeyeria montenigrina. The IUCN Red List of Threatened Species 2010: e.T155489A4786103. Available from http://www.iucnredlist.org/ [accessed 8 Sep. 2017].

Posada D. 2008. jModelTest: Phylogenetic model averaging. Molecular Biology and Evolution 25: 1253-1256. https://doi.org/10.1093/molbev/msn083

Pretner E. 1972. La biospeleologia in Jugoslavia nel dopoguerra. Italian Journal of Zoology 39 (4): 491-502. https://doi.org/10.1080/11250007209431403

Radulović M. \& Radulović V. 2004. Hydrogeological Map of Montenegro 1:200,000. Geological Survey of Montenegro, Podgorica. 
Rambaut A. 2014. FigTree v. 1.4.2. Available from http://tree.bio.ed.ac.uk/software/figtree/ [accessed 12 Oct. 2016].

Rambaut A. \& Drummond A.J. 2007. Tracer v1.4. Distributed by the author.

Rao G.C. \& Clausen C. 1970. Planodasys marginalis gen. et. sp. nov. and Planodasyidae fam. nov. (Gastrotricha Macrodasyoidea). Sarsia 42: 73-82. https://doi.org/10.1080/00364827.1970.10411164

Ronquist F., Teslenko M., van der Mark P., Ayres D.L., Darling A., Höhna S., Larget B., Liu L., Suchard M.A. \& Huelsenbeck J.P. 2012. MrBayes 3.2: efficient Bayesian phylogenetic inference and model choice across a large model space. Systematic Biology 61: 539-542. https://doi.org/10.1093/sysbio/sys029

Roszczak R. 1969. Brzuchorzęski (Gastrotricha) środkowej Wielkopolski. Poznańskie Towarzystwo Przyjaciół Nauk. Wydział matematyczno-przyrodniczy. Prace Komisji Biologicznej 32 (6): 1-92.

Tamura K., Stecher G., Peterson D., Filipski A. \& Kumar S. 2013. MEGA6: Molecular Evolutionary Genetics Analysis Version 6.0. Molecular Biology and Evolution 30 (12): 2725-2729. https://doi.org/10.1093/molbev/mst197

Telford M.J., Lockyer A.E., Cartwright-Finch C. \& Littlewood D.T.J. 2003. Combined large and small subunit ribosomal RNA phylogenies support a basal position of the acoelomorph flatworms. Proceedings of the Royal Society B, Biological Sciences 1519 (270): 1077-1083. https://doi.org/10.1098/rspb.2003.2342

Todaro M.A. 2016. Gastrotricha [online]. Available from World Register of Marine Species at http://www.marinespecies.org/aphia.php? $\mathrm{p}=$ taxdetailsetid=2078 [accessed 7 May 2016].

Todaro M.A. \& Hummon W.D. 2008. An overview and a dichotomous key to genera of the phylum Gastrotricha. Meiofauna Marina 16: 3-20.

Todaro M.A., Leasi F., Bizzarri N. \& Tongiorgi P. 2006. Meiofauna densities and gastrotrich community composition in a Mediterranean sea cave. Marine Biology 149: 1079-1091. https://doi.org/10.1007/s00227-006-0299-z

Vandel A. 1964. Biospeleology. The Biology of Cavernicolous Animals. Pergamon Press, Oxford.

Manuscript received: 13 July 2016

Manuscript accepted: 19 January 2017

Published on: 28 September 2017

Topic editor: Rudy Jocqué

Desk editor: Kristiaan Hoedemakers

Printed versions of all papers are also deposited in the libraries of the institutes that are members of the EJT consortium: Muséum national d'Histoire naturelle, Paris, France; Botanic Garden Meise, Belgium; Royal Museum for Central Africa, Tervuren, Belgium; Natural History Museum, London, United Kingdom; Royal Belgian Institute of Natural Sciences, Brussels, Belgium; Natural History Museum of Denmark, Copenhagen, Denmark; Naturalis Biodiversity Center, Leiden, the Netherlands; Museo Nacional de Ciencias Naturales-CSIC, Madrid, Spain; Real Jardín Botánico de Madrid CSIC, Spain. 


\section{Appendix}

Morphometric parameters of Chaetonotus (Chaetonotus) antrumus Kolicka sp. nov. Abbreviations: $\mathrm{N}=$ number of specimens or structures analysed; Range $=$ the smallest and the largest structure measurement found among all specimens measured; SD = standard deviation. All measurements are given in micrometers $(\mu \mathrm{m})$; all indicators are given as a percentage $(\%)$ and italicized.

\begin{tabular}{|c|c|c|c|c|c|c|c|}
\hline Characters & $\mathbf{N}$ & Holotype & $\begin{array}{c}\text { Range } \\
\text { of adult } \\
\text { paratypes }\end{array}$ & SD & $\mathbf{N}$ & $\begin{array}{c}\text { Range of } \\
\text { juvenile and } \\
\text { subadult } \\
\text { paratypes }\end{array}$ & SD \\
\hline Body length & 11 & 123.08 & $\begin{array}{c}119.12- \\
129.72\end{array}$ & 2.941 & 2 & $91.19-118.46$ & 19.283 \\
\hline Pharynx length & 11 & 32.79 & $31.85-34.85$ & 0.966 & 2 & $30.47-31.05$ & 0.410 \\
\hline $\begin{array}{l}\text { Width of anterior pharynx } \\
\text { thickening (a) }\end{array}$ & 11 & 8.54 & $8.32-10.14$ & 0.522 & 2 & $8.17-8.52$ & 0.247 \\
\hline Width of pharynx narrowing (n) & 11 & 5.81 & $5.06-6.22$ & 0.367 & 2 & $5.25-5.31$ & 0.042 \\
\hline Width of middle pharynx (m) & 11 & 7.04 & $6.51-7.46$ & 0.281 & 2 & $6.76-6.78$ & 0.014 \\
\hline $\begin{array}{l}\text { Width of posterior pharynx } \\
\text { thickening }(p)\end{array}$ & 11 & 9.64 & $9.16-11.28$ & 0.590 & 2 & $8.84-9.05$ & 0.148 \\
\hline $\begin{array}{l}\text { Length of cephalic cilia } \\
\text { (anterior tuft) }\end{array}$ & 10 & $6.27-16.04$ & $\begin{array}{l}(5.46-6.86)- \\
(14.54-7.21)\end{array}$ & $0.421 ; 0.873$ & 2 & $\begin{array}{l}(5.43-5.77)- \\
(15.94-6.01)\end{array}$ & $\begin{array}{l}0.247 \\
0.049\end{array}$ \\
\hline $\begin{array}{l}\text { Length of cephalic cilia } \\
\text { (posterior tuft) }\end{array}$ & 10 & $8.74-18.35$ & $\begin{array}{l}(7.94-9.07)- \\
(18.16-0.74)\end{array}$ & $0.368 ; 0.822$ & 2 & $\begin{array}{l}(8.26-8.28)- \\
(17.82-7.96)\end{array}$ & $\begin{array}{c}0.014 \\
0.099\end{array}$ \\
\hline Hypostomium length & 10 & 5.29 & $4.56-6.08$ & 0.438 & 2 & $4.19-5.14$ & 0.672 \\
\hline Hypostomium width & 10 & 6.58 & $5.73-6.97$ & 0.395 & 2 & $5.26-6.09$ & 0.587 \\
\hline Cephalion length & 10 & 9.29 & $8.92-10.71$ & 0.632 & 2 & $8.86-9.02$ & 0.113 \\
\hline Cephalion width & 10 & 8.82 & $8.33-9.41$ & 0.291 & 2 & $7.81-8.40$ & 0.417 \\
\hline Cephalion maximum width & 10 & 11.37 & $11.14-12.18$ & 0.375 & 2 & $10.94-11.34$ & 0.283 \\
\hline Diameter of mouth ring & 10 & 4.67 & $4.24-4.84$ & 0.174 & 2 & $4.37-4.46$ & 0.064 \\
\hline Furca length & 10 & 21.71 & $19.77-23.24$ & 0.868 & 2 & $20.82-21.39$ & 0.403 \\
\hline Length of adhesive tube & 10 & 10.39 & $10.08-11.26$ & 0.361 & 2 & $10.02-10.07$ & 0.035 \\
\hline Width of adhesive tube & 10 & 1.29 & $1.26-1.34$ & 0.029 & 2 & $1.23-1.27$ & 0.028 \\
\hline Length of head scales & 10 & $1.91-3.50$ & $\begin{array}{l}(1.57-2.19)- \\
(3.34-3.82)\end{array}$ & $0.219 ; 0.182$ & 2 & $\begin{array}{l}(1.49-1.56)- \\
(3.28-3.32)\end{array}$ & $\begin{array}{c}0.049 \\
0.028\end{array}$ \\
\hline Width of head scales & 10 & $2.04-4.14$ & $\begin{array}{l}(1.78-2.32)- \\
(3.56-4.26)\end{array}$ & $0.207 ; 0.214$ & 2 & $\begin{array}{l}(1.62-1.69)- \\
(3.59-3.94)\end{array}$ & $\begin{array}{l}0.049 \\
0.247\end{array}$ \\
\hline Length of neck scales & 10 & $1.39-3.14$ & $\begin{array}{l}(1.27-1.82)- \\
(2.93-3.29)\end{array}$ & $0.173 ; 0.130$ & 2 & $\begin{array}{l}(1.24-1.37)- \\
(2.89-3.06)\end{array}$ & $\begin{array}{c}0.092 \\
0.120\end{array}$ \\
\hline Width of neck scales & 10 & $1.66-3.05$ & $\begin{array}{l}(1.42-2.04)- \\
(2.76-3.94)\end{array}$ & $0.195 ; 0.345$ & 2 & $\begin{array}{l}(1.47-1.57)- \\
(2.76-2.84)\end{array}$ & $\begin{array}{l}0.071 \\
0.057\end{array}$ \\
\hline Length of trunk scales & 10 & $2.76-4.52$ & $\begin{array}{l}(2.47-3.02)- \\
(4.12-5.61)\end{array}$ & $0.185 ; 0.453$ & 2 & $\begin{array}{l}(2.38-2.61)- \\
(4.10-4.23)\end{array}$ & $\begin{array}{l}0.163 \\
0.092\end{array}$ \\
\hline
\end{tabular}


KOLICKA M. et al., New species of Chaetonotus from cave

\begin{tabular}{|c|c|c|c|c|c|c|c|}
\hline Characters & $\mathbf{N}$ & Holotype & $\begin{array}{c}\text { Range } \\
\text { of adult } \\
\text { paratypes }\end{array}$ & SD & $\mathbf{N}$ & $\begin{array}{c}\text { Range of } \\
\text { juvenile and } \\
\text { subadult } \\
\text { paratypes }\end{array}$ & SD \\
\hline Width of trunk scales & 10 & $1.84-3.43$ & $\begin{array}{c}(1.64-2.04)- \\
(3.10-4.27)\end{array}$ & $0.153 ; 0.347$ & 2 & $\begin{array}{c}(1.59-1.70)- \\
(2.92-3.08)\end{array}$ & $\begin{array}{l}0.078 \\
0.113\end{array}$ \\
\hline $\begin{array}{l}\text { Length of small one-lobed } \\
\text { scales }\end{array}$ & 10 & 2.12 & $1.88-2.66$ & 0.267 & 2 & $1.62-2.88$ & 0.891 \\
\hline Width of small one-lobed scales & 10 & 1.51 & $1.32-1.78$ & 0.150 & 2 & $1.08-1.56$ & 0.339 \\
\hline $\begin{array}{l}\text { Length of furcal appendages } \\
\text { one-lobed scales }\end{array}$ & 10 & $4.55-4.72$ & $\begin{array}{l}(4.02-5.23)- \\
(4.32-5.72)\end{array}$ & $0.395 ; 0.461$ & 2 & $\begin{array}{l}(3.83-4.06)- \\
(4.09-4.27)\end{array}$ & $\begin{array}{l}0.163 ; \\
0.127\end{array}$ \\
\hline $\begin{array}{l}\text { Width of furcal appendages } \\
\text { one-lobed scales }\end{array}$ & 10 & $2.21-2.42$ & $\begin{array}{c}(2.02-2.71)- \\
(2.08-3.17)\end{array}$ & $0.208 ; 0.308$ & 2 & $\begin{array}{l}(1.77-1.94)- \\
(1.92-2.03)\end{array}$ & $\begin{array}{l}0.120 ; \\
0.078\end{array}$ \\
\hline $\begin{array}{l}\text { Length of both pairs of } \\
\text { parafurcal scales }\end{array}$ & 10 & $2.76-2.81$ & $\begin{array}{c}(2.04-3.38)- \\
(2.53-3.60)\end{array}$ & $0.299 ; 0.324$ & 2 & $\begin{array}{c}(2.41-2.54)- \\
(2.54-2.73)\end{array}$ & $\begin{array}{l}0.092 ; \\
0.134\end{array}$ \\
\hline Width of parafurcal scales & 10 & $2.27-2.34$ & $\begin{array}{l}(2.11-2.82)- \\
(2.21-3.22)\end{array}$ & $0.239 ; 0.314$ & 2 & $\begin{array}{c}(1.87-2.04)- \\
(2.04-2.16)\end{array}$ & $\begin{array}{l}0.120 ; \\
0.085\end{array}$ \\
\hline Length of head spines & 10 & $1.14-2.06$ & $\begin{array}{c}(1.05-1.48)- \\
(1.83-3.09)\end{array}$ & $0.164 ; 0.365$ & 2 & $\begin{array}{l}(1.01-1.09)- \\
(1.97-2.03)\end{array}$ & $\begin{array}{l}0.057 \\
0.042\end{array}$ \\
\hline $\begin{array}{l}\text { Length of head hair-like ventral } \\
\text { spines }\end{array}$ & 10 & $5.51-6.88$ & $\begin{array}{c}(5.09-6.38)- \\
(6.38-8.55)\end{array}$ & $0.437 ; 0.716$ & 2 & $\begin{array}{l}(4.94-5.18)- \\
(5.67-6.33)\end{array}$ & $\begin{array}{l}0.170 \\
0.467\end{array}$ \\
\hline Length of neck spines & 10 & $0.61-1.72$ & $\begin{array}{c}(0.47-1.26)- \\
(1.53-2.67)\end{array}$ & $0.220 ; 0.329$ & 2 & $\begin{array}{l}(0.51-0.53)- \\
(1.63-1.76)\end{array}$ & $\begin{array}{l}0.014 \\
0.092\end{array}$ \\
\hline $\begin{array}{l}\text { Length of neck hairlike ventral } \\
\text { spines }\end{array}$ & 10 & $5.36-7.24$ & $\begin{array}{c}(4.98-6.25)- \\
(6.89-9.02)\end{array}$ & $0.430 ; 0.683$ & 2 & $\begin{array}{l}(4.57-4.97)- \\
(6.12-6.86)\end{array}$ & $\begin{array}{l}0.283 \\
0.523\end{array}$ \\
\hline Length of trunk spines & 10 & $1.50-2.97$ & $\begin{array}{l}(1.33-1.94)- \\
(2.52-4.12)\end{array}$ & $0.176 ; 0.448$ & 2 & $\begin{array}{l}(1.29-1.39)- \\
(2.72-2.74)\end{array}$ & $\begin{array}{l}0.071 ; \\
0.014\end{array}$ \\
\hline $\begin{array}{l}\text { Length of trunk hair-like ventral } \\
\text { spines }\end{array}$ & 10 & $7.31-12.09$ & $\begin{array}{l}(7.08-9.16)- \\
(10.49-13.96)\end{array}$ & $0.664 ; 1.021$ & 2 & $\begin{array}{l}(6.24-6.97)- \\
(10.49-10.52)\end{array}$ & $\begin{array}{l}0.516 ; \\
0.021\end{array}$ \\
\hline $\begin{array}{l}\text { Length of posteriormost trunk } \\
\text { lateral spines }\end{array}$ & 10 & 3.77 & $3.39-5.93$ & 0.721 & 2 & $3.52-3.61$ & 0.064 \\
\hline $\begin{array}{l}\text { Length of furcal appendages } \\
\text { dorsal spines }\end{array}$ & 10 & 2.64 & $2.42-4.08$ & 0.530 & 2 & $2.23-2.33$ & 0.071 \\
\hline Length of parafurcal spines & 10 & 6.02 & $5.53-7.67$ & 0.639 & 2 & $5.47-5.61$ & 0.099 \\
\hline $\begin{array}{l}\text { Length of ventral interciliary } \\
\text { field scales }\end{array}$ & 11 & $1.93-3.44$ & $\begin{array}{l}(1.44-1.93)- \\
(3.08-3.72)\end{array}$ & $0.202 ; 0.230$ & 2 & $\begin{array}{l}(1.52-1.73)- \\
(3.10-3.19)\end{array}$ & $\begin{array}{l}0.148 \\
0.064\end{array}$ \\
\hline $\begin{array}{l}\text { Width of ventral interciliary } \\
\text { field scales }\end{array}$ & 11 & $1.21-1.68$ & $\begin{array}{l}(1.07-1.29)- \\
(1.56-1.88)\end{array}$ & $0.059 ; 0.111$ & 2 & $\begin{array}{l}(1.06-1.12)- \\
(1.59-1.62)\end{array}$ & $\begin{array}{l}0.042 ; \\
0.021\end{array}$ \\
\hline $\begin{array}{l}\text { Length of posteriormost ventral } \\
\text { interciliary field scales }\end{array}$ & 11 & 5.91 & $5.37-6.12$ & 0.231 & 2 & $5.46-5.62$ & 0.113 \\
\hline $\begin{array}{l}\text { Width of posteriormost ventral } \\
\text { interciliary field scales }\end{array}$ & 11 & 2.37 & $2.22-3.24$ & 0.279 & 2 & $2.19-2.24$ & 0.035 \\
\hline Head dorsal sensory bristles & 11 & 8.41 & $8.19-10.13$ & 0.569 & 2 & $8.28-8.47$ & 0.134 \\
\hline
\end{tabular}




\begin{tabular}{|c|c|c|c|c|c|c|c|}
\hline Characters & $\mathbf{N}$ & Holotype & $\begin{array}{c}\text { Range } \\
\text { of adult } \\
\text { paratypes }\end{array}$ & SD & $\mathbf{N}$ & $\begin{array}{l}\text { Range of } \\
\text { juvenile and } \\
\text { subadult } \\
\text { paratypes }\end{array}$ & SD \\
\hline $\begin{array}{l}\text { Neck dorsal sensory bristles } \\
\text { length }\end{array}$ & 11 & 14.77 & $13.28-15.68$ & 0.796 & 2 & $13.28-13.94$ & 0.467 \\
\hline $\begin{array}{l}\text { Posterior dorsal sensory bristles } \\
\text { length }\end{array}$ & 11 & 11.72 & $10.13-12.67$ & 0.755 & 2 & $10.01-11.08$ & 0.757 \\
\hline Length of mature egg & 1 & - & 40.96 & - & - & - & - \\
\hline Width of mature egg & 1 & & 26.02 & & - & - & - \\
\hline $\begin{array}{l}\text { Number of cephalic cilia in } \\
\text { anterior tuft }\end{array}$ & 31 & 4 & 4 & 0 & 5 & 4 & 0 \\
\hline $\begin{array}{l}\text { Number of cephalic cilia in } \\
\text { posterior tuft }\end{array}$ & 31 & 5 & 5 & 0 & 5 & 5 & 0 \\
\hline $\begin{array}{l}\text { Number of scales in central } \\
\text { longitudinal row }\end{array}$ & 31 & 25 & $24-27$ & 1.104 & 5 & $23-26$ & 2.121 \\
\hline $\begin{array}{l}\text { Total number of longitudinal } \\
\text { alternating rows of scales }\end{array}$ & 31 & 31 & $29-35$ & 1.748 & 5 & $29-31$ & 1.414 \\
\hline $\begin{array}{l}\text { Number of scales in single } \\
\text { longitudinal row on ventral } \\
\text { interciliary field }\end{array}$ & 31 & 3 & $3-4$ & 0.467 & 5 & 3 & 0 \\
\hline $\begin{array}{l}\text { Total number of longitudinal } \\
\text { alternating rows of scales }\end{array}$ & 31 & 9 & $7-9$ & 0.809 & 5 & 9 & 0 \\
\hline Pharynx formula a & 11 & 26.045 & $\begin{array}{l}24.317- \\
29.096\end{array}$ & 1.406 & 2 & $\begin{array}{l}26.312- \\
27.962\end{array}$ & 1.167 \\
\hline Pharynx formula $n$ & 11 & 17.719 & $\begin{array}{c}15.852- \\
19.036\end{array}$ & 1.028 & 2 & $\begin{array}{c}16.908- \\
17.427\end{array}$ & 0.367 \\
\hline Pharynx formula $\mathrm{m}$ & 11 & 21.47 & $\begin{array}{c}20.331- \\
22.732\end{array}$ & 0.800 & 2 & $\begin{array}{c}21.771- \\
22.251\end{array}$ & 0.339 \\
\hline Pharynx formula $\mathrm{p}$ & 11 & 29.399 & $\begin{array}{c}27.607- \\
32.367\end{array}$ & 1.560 & 2 & $\begin{array}{l}29.012- \\
29.147\end{array}$ & 0.095 \\
\hline Ratio of scale distribution & 31 & 124 & $111.5-129.6$ & 4.912 & 5 & $119.2-126.1$ & 4.879 \\
\hline
\end{tabular}

